\title{
Localization of Calcium Signals by a Mobile Calcium Buffer in Frog Saccular Hair Cells
}

\author{
William M. Roberts \\ Institute of Neuroscience, University of Oregon, Eugene, Oregon 97403
}

A recent study (Roberts, 1993) of saccular hair cells from grass frogs (Rana pipiens) has suggested a mechanism by which the unusually high concentrations of calcium-binding proteins found in certain sensory receptors and neurons, particularly in the auditory system, can influence short-range intracellular calcium signaling. In frog saccular hair cells, the mechanism operates within arrays of calcium channels and calcium-activated potassium channels that are involved in the cells' electrical resonance and synaptic transmission. The present study tests the hypothesis that calbindin-D28k, one of the most abundant proteins in these cells, can serve as a mobile calcium buffer that reduces and localizes changes in the intracellular free-calcium concentration $\left(\left[\mathrm{Ca}^{2+}\right]_{i}\right)$ by shuttling calcium away from the channel arrays. Based upon theoretical analysis and computer modeling, it is shown that


steady-state level determined primarily by two properties of the buffer, the mean time $\left(\tau_{c}\right)$ before it captures a free-calcium ion and a replenishment factor $(R)$, which are related to the buffer's diffusional mobility $\left(D_{\mathrm{Bu}}\right)$, association rate constant $\left(k_{\mathrm{our}}\right)$, and concentration $\left(B_{0}\right)$ by $\tau_{c}=\left(k_{\mathrm{on}} B_{0}\right)^{-1}$ and $R=$ $B_{0} D_{\mathrm{Bu}}$. Simulation of calcium entry through a channel array showed that $\sim 1.5 \mathrm{~mm}$ of a molecule with the diffusional and binding properties expected for calbindin-D28K $\left(B_{0} \approx 8 \mathrm{mM}\right.$ calcium-binding sites) is needed to reproduce the previous experimental results. A lower concentration $\left(B_{0}=2 \mathrm{~mm}\right.$ ) was almost completely depleted within the channel array by a modest calcium current ( $8 \mathrm{pA}=12 \%$ of calcium channels open), but still had two important effects: it caused $\left[\mathrm{Ca}^{2+}\right]_{i}$ to fall steeply with distance outside the array (space constant $<50 \mathrm{~nm})$, and returned $\left[\mathrm{Ca}^{2+}\right]_{i}$ quickly to the resting level after the channels closed. A high concentration of calbindin-D28k can thus influence the cell's electrical resonance and synaptic transmission. Its most important functions may be to localize regions of high $\left[\mathrm{Ca}^{2+}\right]_{i}$ and speed the return of $\left[\mathrm{Ca}^{2+}\right]_{;}$toward the resting level.

[Key words: calcium buffer, calcium-binding protein, calcium diffusion, facilitated diffusion, intracellular calcium, calbindin-D28k, calcium channel, calcium-activated potassium channel, hair cell, electrical frequency tuning, synapse, vestibular system, auditory system]

\footnotetext{
Received Sept. 8, 1993; revised Oct. 28, 1993; accepted Nov. 17, 1993.

I thank Drs. A. J. Hudspeth, J. C. Weeks, and R. S. Zucker for insightful discussion and comments on the manuscript, and J. C. Weeks for help with English translation. This study was supported by National Institutes of Health Grant NS27 142, an Alfred P. Sloan Foundation fellowship, and a Scholars Award from the McKnight Endowment Fund for Neuroscience.

Correspondence should be addressed to Dr. W. M. Roberts at the above address. Copyright (C) 1994 Society for Neuroscience $0270-6474 / 94 / 143246-17 \$ 05.00 / 0$
}

For calcium to regulate extremely rapid and precisely timed processes, its sources and receptors must be close together. In fast synaptic transmission, where calcium can act with a delay of $<200 \mu \mathrm{sec}$ (Llinás et al., 1981; Augustine et al., 1985), the distance between the channels that admit calcium into the cell and the receptors that initiate exocytosis is thought to be $\sim 50$ $\mathrm{nm}$, little more than the diameter of a synaptic vesicle (Fogelson and Zucker, 1985). At this distance, $\left[\mathrm{Ca}^{2+}\right]_{i}$ can rise 1000 -fold (>100 $\mu \mathrm{M}$ ) in a few microseconds after a single calcium channel opens, and then return more slowly to the resting level when the channel closes (Simon and Llinás, 1985; Yamada and Zucker, 1992). Such high calcium concentrations arc essential to reduce the time required for calcium ions to bind to receptors. Early models of calcium diffusion, which assumed that $>95 \%$ of the calcium was captured instantaneously by cytoplasmic buffers (Zucker and Stockbridge, 1983; Chad and Eckert, 1984; Stockbridge and Moore, 1984), and early measurements of $\left[\mathrm{Ca}^{2+}\right]_{i}$, which lacked spatial resolution, seemed inconsistent with such high free-calcium concentrations. However, nore recent models that use realistic association rates (Connor and Nikolakopoulou, 1982; Fogelson and Zucker, 1985; Simon and Llinás, 1985; Neher, 1986; Zucker and Fogelson, 1986; Parnas et al., 1989; Sala and Hernández-Cruz, 1990; Yamada and Zucker, 1992; Nowycky and Pinter, 1993) support the existence of localized calcium concentrations above $100 \mu \mathrm{M}$. Methods capable of detecting highly localized regions of very high $\left[\mathrm{Ca}^{2+}\right]_{i}$ have provided experimental evidence for calcium concentrations above $100 \mu \mathrm{M}$ (Roberts et al., 1990; Llinás et al., 1992).

Because the concentration gradient within $100 \mathrm{~nm}$ of a calcium channel is extremely steep, and the precise spatial arrangement of channels and receptors therefore critical, it is not surprising that channels are often found in orderly arrays in the presynaptic membrane (Heuser et al., 1974; Hama, 1980; Pumplin et al., 1981; Walrond and Reese, 1985; reviewed by Smith and Augustine, 1988; Engel, 1991). These arrays probably reflect the organization of structures that align channels with receptors and other components of the exocytotic machinery. They also serve to bring tens or hundreds of calcium channels close together. If the density of calcium channels in an array is great enough, the domains of high calcium surrounding individual channels merge into a larger region, throughout which $\left[\mathrm{Ca}^{2+}\right]$ may reach hundreds of micromolar cncentrations (Roberts et al., 1990, 1991). The simulations presented in this report show that, during even a weak depolarization of a frog saccular hair cell, this region probably encompasses the entire $250-\mathrm{nm}$-diameter channel array at each presynaptic active zone. At active zones in some other cells, calcium domains around individual channels may not overlap extensively (reviewed by Augustine et al., 1991), perhaps because channel arrays are too sparse or have the wrong shape (linear rather than circular). 
The extent to which regions of high calcium around individual channels overlap is determined by the passive properties of calcium diffusion and buffering in the cytoplasm. Active transport of calcium out of the cell can have little effect within a few hundred nanometers of a channel cluster because it would be impossible to pack into this small area of membrane the thousands of calcium pumps or exchangers needed to balance the influx through each open channel (Roberts et al., 1991). Likewise, for uptake into intracellular compartments to be significant, they would have to be packed at great density in a small volume of cytoplasm around each channel. Even calcium-binding proteins, which buffer $\left[\mathrm{Ca}^{2+}\right]_{i}$ by capturing free ions, will have little effect this close to a source if all available sites are quickly saturated. To avoid saturation, a calcium buffer must itself be capable of rapid diffusion. Diffusion allows the calciumbound buffer to carry calcium away, while the calcium-free buffer is continually replenished. $\Lambda$ s will be shown below, a mobile buffer can profoundly affect the accumulation of free calcium near a cluster of channels, as well as the amount of free calcium that travels deeper into the cell interior. The buffer may thus influence both fast processes that trigger exocytosis, and slower processes like posttetanic potentiation that are controlled by smaller changes in $\left[\mathrm{Ca}^{2+}\right]_{i}$ throughout the presynaptic terminal (Delaney et al., 1989, 1991; Swandulla et al., 1991).

Large clusters of calcium channels allow for rapid rises in $\left[\mathrm{Ca}^{2+}\right]_{i}$ but create difficulties in returning it quickly to the resting level. If one visualizes the spatial distribution of free calcium at the intracellular face of the membrane as a landscape, with height representing the calcium concentration, then opening a calcium channel erects a tall spire above the channel. When the channel closes, the spire loses its support and collapses within $1 \mu \mathrm{sec}$, leaving behind a smooth mound of residual calcium that slowly spreads as it flattens back to the resting level (Simon and Llinás, 1985). The mound, though much lower than the spire, persists for hundreds of milliseconds, during which time $\left[\mathrm{Ca}^{2+}\right]_{i}$ can remain at $>1 \mu \mathrm{M}$ throughout a region extending more than $1 \mu \mathrm{m}$ from the channel. Near a cluster of channels, the individual mounds can combine to form a hill more than $10 \mu \mathrm{M}$ high. Such extensive regions of high $\left[\mathrm{Ca}^{2+}\right]_{i}$ might desynchronize events that rely on extremely brief calcium signals, and could have other serious consequences, including cell death (Mattson et al., 1991). Therefore, cells that contain large clusters of calcium channels or are repetitively active at high rates may need to hasten the collapse of the residual calcium mounds.

Based on experiments using frog saccular hair cells (Roberts, 1993), I have proposed that some hair cells use the calbindinD28k or related calcium-binding proteins, which are present at high concentrations throughout their cytoplasm (Dechesne and Thomasset, 1988; Dechesne et al., 1988a,b, 1991; Oberholtzer et al., 1988; Rogers, 1989; Shepherd et al., 1989; Gillespie and Hudspeth, 1991), to expedite the decline in $\left[\mathrm{Ca}^{2+}\right]_{i}$ after channel closure. According to this hypothesis, calbindin serves as a mobile calcium buffer that captures most of the incoming calcium in $<100 \mu \mathrm{sec}$. By carrying this bound calcium away from the site of entry, it confines the local rise in $\left[\mathrm{Ca}^{2+}\right]_{i}$ to an extremely small volume and rapidly restores $\left[\mathrm{Ca}^{2+}\right]_{i}$ to its resting level after channels close. The present modeling study tests the feasibility of this mechanism and provides the theoretical basis for estimating the buffer's concentration and binding rate from experimental data.

The proposed mechanism involves three essential steps (Fig. 1): (1) the binding of calcium to a cytoplasmic buffer, (2) the

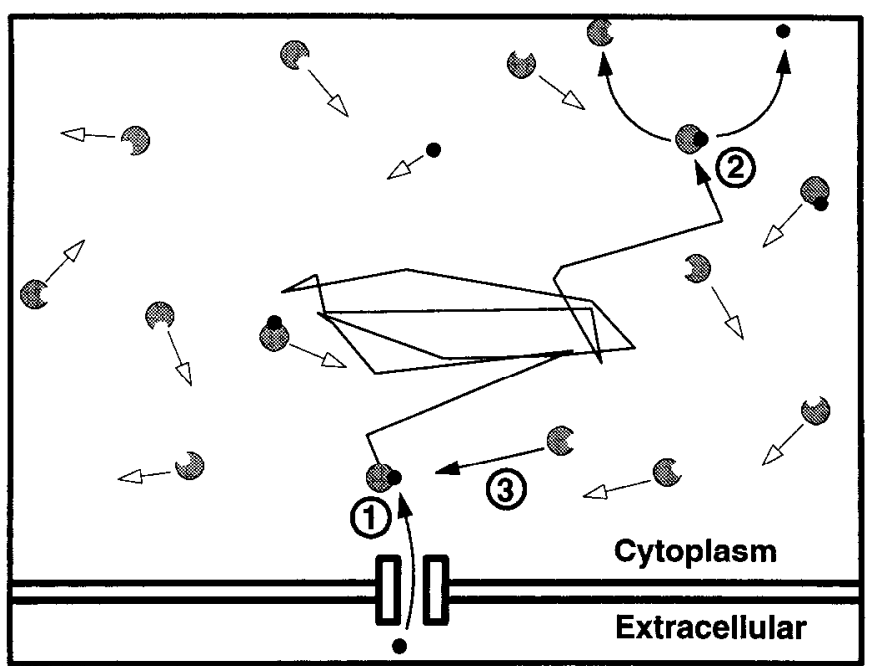

Figure 1. Schematic diagram of the buffered diffusion model. The cytoplasm (top compartment) contains a high concentration of one or more small calcium-binding proteins (shaded circles) that are free to diffuse. Initially, $\left[\mathrm{Ca}^{2+}\right]_{i}$ is lower than the buffer's dissociation constant $\left(K_{d}\right)$, so most of the calcium-binding sites (indentations in shaded circles) are unoccupied. A calcium ion (solid circle) entering through a channel (1) encounters and binds to an unoccupied buffer molecule. The buffer holds the calcium ion for several milliseconds (on average), long enough to wander $\sim 1 \mu \mathrm{M}$ (2) before releasing it. Meanwhile, other calcium-free binding proteins diffuse into the vicinity of the channel (3), ready to capture the next ion. Arrows denote diffusion (i.e., random movement the buffer and calcium).

diffusion of calcium-bound buffer away from the point of calcium entry, and (3) the replenishment of calcium-free buffer from the surrounding volume of cytoplasm. A related mechanism has previously been described as the "facilitated diffusion" of calcium through epithelial cells (Bronner, 1989; Feher et al., 1989, 1992). This usage is somewhat confusing because the same term is commonly used to describe processes that assist the movement of lipophobic molecules across cell membranes, in which case diffusion truly is facilitated (i.e., the rate of movement is increased). In the case of calcium binding to a mobile cytoplasmic protein, bound calcium diffuses slower than free calcium. Rather than speeding diffusion, it allows calcium to travel in an inactive form (i.e., bound to a carrier protein). This process will be called "buffered diffusion" in this article. Buffered diffusion is entirely passive, involving simply the reversible binding of calcium to a buffer and diffusion of the calciumbuffer complex down its concentration gradient.

The possible effects of high concentrations of mobile calcium buffers have not previously been investigated over the short time and distance scales relevant to fast calcium-mediated processes. Previous theoretical treatments of buffered diffusion in epithelial cells (Feher et al., 1989, 1992)), neurons (Connor and Nikolakopoulou, 1982; Sala and Hernández-Cruz, 1990; Nowycky and Pinter, 1993), and other cells (Kutchai et al., 1970; Speksnijder et al., 1989) have considered spatially diffuse calcium entry through large regions of the cellular surface, rather than through a tight clustcr of channels. Simon and Llinás (1985) modeled buffered calcium diffusion near an array of channels, but with a low concentration $(50 \mu \mathrm{M})$ of mobile calcium buffer. One theoretical report (Neher, 1986) has also considered buffered diffusion away from a point source, but in the simple case in which the local depletion of the mobile buffer was ignored (i.e., for small calcium currents). However, local depletion is 
Table 1. Definitions of symbols and their standard values

\begin{tabular}{|c|c|c|}
\hline Name & Definition & Standard value \\
\hline \multicolumn{3}{|c|}{ Constants } \\
\hline$C_{0}$ & $\begin{array}{l}\text { Initial (resting) concentration of } \\
\text { free calcium in the cytoplasm; } \\
\text { spatially uniform }\end{array}$ & $<1 \mu \mathrm{M}$ \\
\hline$D_{C a}$ & $\begin{array}{l}\text { Coefficient of diffusion for free } \\
\text { calcium in cytoplasm }\end{array}$ & $200 \mu \mathrm{m}^{2} \mathrm{sec}^{-1}$ \\
\hline$D_{\mathrm{Bu}}$ & $\begin{array}{l}\text { Coefficient of diffusion for the } \\
\text { buffer in cytoplasm; applies to } \\
\text { both calcium-free and calcium- } \\
\text { bound buffer }\end{array}$ & $20 \mu \mathrm{m}^{2} \mathrm{sec}^{-1}$ \\
\hline$B_{\mathrm{ios}}$ & $\begin{array}{l}\text { Concentration of mobile calcium } \\
\text { binding sites (i.e., the concen- } \\
\text { tration of calcium buffer times } \\
\text { the number of calcium binding } \\
\text { sites per molecule of buffer); } \\
\text { includes calcium-bou } l \text { and } \\
\text { calcium-free sites; spatially uni- } \\
\text { form }\end{array}$ & $B_{0}\left(K_{d}+C_{0}\right) / C_{0}$ \\
\hline$B_{0}$ & $\begin{array}{l}\text { Initial concentration of calcium- } \\
\text { free mobile calcium binding } \\
\text { sites (in equilibrium with } C_{0} \text { ) }\end{array}$ & $2 \mathrm{~mm}$ \\
\hline$K_{d}$ & $\begin{array}{l}\text { Dissociation constant for calcium } \\
\text { from buffer }\end{array}$ & $1 \mu \mathbf{M}-C_{0}$ \\
\hline$k_{\text {on }}$ & $\begin{array}{l}\text { Rate constant for calcium bind- } \\
\text { ing to the buffer }\end{array}$ & $1.5 \times 10^{8} \mathrm{M}^{-1} \sec ^{-1}$ \\
\hline$k_{\text {off }}$ & $\begin{array}{l}\text { Rate constant for calcium disso- } \\
\text { ciation from the buffer }\end{array}$ & $k_{d} k_{\mathrm{on}}$ \\
\hline$I_{\mathrm{sc}}$ & $\begin{array}{l}\text { Current through a single open } \\
\text { calcium channel at }-50 \mathrm{mV}\end{array}$ & $0.8 \mathrm{pA}$ \\
\hline$\tau_{c}$ & $\begin{array}{l}\text { Mean time for the buffer to cap- } \\
\text { ture a free calcium ion at the } \\
\text { initial buffer concentration: } \tau_{c} \\
=\left(k_{\mathrm{on}} B_{0}\right)^{-1}\end{array}$ & $3.3 \mu \mathrm{sec}$ \\
\hline Variab & $\begin{array}{l}\text { Factor that determines the buf- } \\
\text { fer's effectiveness when deplet- } \\
\text { ed near the source of calcium: } \\
R=D_{\mathrm{Bu}} B_{\mathrm{o}} \\
\text { be calculated in the simulations }\end{array}$ & $40 \mathrm{fm} \mathrm{m}^{2} \mathrm{sec}^{-1}$ \\
\hline$C$ & $\begin{array}{l}\text { Change in free calcium from the } \\
\text { resting level: } C=\left[\mathrm{Ca}^{2+}\right]_{i}-C_{0} \text {; } \\
\text { varies in time and space; ini- } \\
\text { tially, } C=0 \text { at every point in } \\
\text { the cytoplasm. }\end{array}$ & \\
\hline$B$ & $\begin{array}{l}\text { Concentration of calcium-free } \\
\text { buffer; varies in time and } \\
\text { space; initially, } B=B_{0} \text { at every } \\
\text { point in the cytoplasm }\end{array}$ & \\
\hline$C_{\mathrm{ss}}$ & $\begin{array}{l}\text { Steady-state value of } C \text {; varies } \\
\text { with position }\end{array}$ & \\
\hline$B_{\mathrm{ss}}$ & $\begin{array}{l}\text { Steady-state value of } B \text {; varies } \\
\text { with position }\end{array}$ & \\
\hline
\end{tabular}

This table lists the constants and variables used in the buffered diffusion model. Unless explicitly stated otherwise, the standard values were used for all simulations. shown here to be a crucial factor that requires that the cell use a buffer that is either very mobile or very concentrated if it is to be effective at sites of large calcium influx. The three main goals of the present study were (1) to provide a general understanding of the possibilities and limitations of buffered diffusion from point sources, (2) to provide the theoretical basis for the interpretation of experimental data, and (3) to incorporate previous physiological and anatomical data into a model of the presynaptic calcium concentration in frog saccular hair cells.

\section{Materials and Methods}

\section{Geometrical assumptions}

Two models of the cytoplasmic space were used, one using simple geometrical assumptions (diffusion from a single point into a large volume), the other incorporating more spatial details. There were two main reasons for beginning with the simple model. On a conceptual level, it allows one to understand the basic principles of buffered diffusion without introducing unnecessary complexity. On a computational level, it makes the calculation of the complete time course of changes in $\left[\mathrm{Ca}^{2+}\right]_{i}$ tractable. This model is useful for understanding the effect of a mobile buffer on $\left[\mathrm{Ca}^{2+}\right]$, near a single channel, or far enough from a cluster of channels that they appear as a single point source. The second model was needed to investigate the spatial variations in $\left[\mathrm{Ca}^{2+}\right]_{i}$ within a cluster of channels, and to relate the simulations to previous experimental data. The price of the greater spatial detail in the second model was the greatly increased computation time, which made it impractical to calculate the time course of changes in $\left[\mathrm{Ca}^{2+}\right]_{i}$. Instead, only the steady-state $\left[\mathrm{Ca}^{2+}\right]_{i}$ was calculated. As will be shown below, this steady-state calculation is useful for understanding the calcium concentration profile within an array of channels during maintained depolarizations. No attempt was made to incorporate the hair cell's overall shape or size into either model because, on the distance scale of interest here, the hair cell's plasma membrane is nearly flat and the cytoplasmic volume nearly infinite (see below).

\section{Initial and boundary conditions}

In the simple model, calcium was assumed to enter at the point in the center of the flat side of a $10-\mu \mathrm{m}$-radius hemisphere and be removed at the far boundary by a process that held $\left[\mathrm{Ca}^{2+}\right]_{\text {i constant at the far }}$ boundary. The details of the calcium removal process were not specified because small changes in $\left[\mathrm{Ca}^{2+}\right]_{i}$ at the far boundary would have little

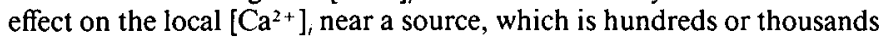
of times higher. The modcl is thus appropriatc for physiological rates of calcium entry, but not for sustained massive calcium influx that overwhelms the cell's ability to extrude calcium (Roberts, 1993). For simplicity, the model excluded calcium extrusion across the membrane surface (i.e., the flat surface of the hemisphere). As mentioned above, calcium transporters would have to be highly concentrated near channels to significantly lower $\left[\mathrm{Ca}^{2+}\right]$, locally. The hemispherical shape was chosen because its radial symmetry simplified the computation.

Although the volume of a $10-\mu \mathrm{m}$-radius hemisphere is smaller than a frog saccular hair cell (Roberts et al., 1990), there is little benefit in modeling a larger space. The effect of the finite radius can easily be computed for unbuffered diffusion, by comparing the calculated values of $\left[\mathrm{Ca}^{2+}\right]_{i}$ to the theoretical values for diffusion from a point source into an infinite volume (Crank, 1975). Within $500 \mathrm{~nm}$ of the source, the difference was $<5 \%$. The effect of the finite volume was even less with a mobile buffer, which caused $\left[\mathrm{Ca}^{2+}\right]$ to fall much more steeply with distance from the source (Neher, 1986; see also below). The geometrical assumptions are therefore appropriate for buffered diffusion in hair cells, but not for smaller presynaptic terminals. Although the same basic principles apply, accurate modeling of calcium diffusion in the confines of a small presynaptic terminal would require knowledge of its size and shape.

A different geometry was used for the more computationally intensive simulation of calcium entry through an array of channels. To reduce the computation time, only a $2 \mu \mathrm{m}$ cube of cytoplasm was modeled. Calcium entered through a cluster of channels located near the center of one face. Because this volume was assumed to be part of a larger intracellular space, both calcium and buffer were allowed to cross the distant boundaries (i.e., the five faces of the cube that did not contain the channel cluster). At these boundaries, $\left[\mathrm{Ca}^{2+}\right]_{i}$ and the concentration of calcium-free buffer ( $B$; see Table 1 for definitions of variables) were 
constrained to remain at their initial values. There is a small error associated with these boundary conditions, which can be estimated using the hemisphere model. At the distance of the closest face of the cube ( $1 \mu \mathrm{m}$ from the center), the steady-state value of $\left[\mathrm{Ca}^{2+}\right]_{i}$ during the largest calcium current studied $(8 \mathrm{pA})$ was slightly increased $\left(C_{\mathrm{ss}} \approx 200 \mathrm{nM}\right.$; see Fig. $5 A$ ), while $B_{\mathrm{ss}}$ was reduced by $14 \%$ (see Fig. $5 B$ ) from its initial value of $B_{0}$. This change in $C_{\mathrm{ss}}$ is insignificant compared to the thousandfold larger changes within the clusters (see Figs. 7-11); the assumption that $B=B_{0}$ at the boundary caused the values of $B$ to be slightly overestimated throughout the cubical volume.

Simulations began with all calcium channels closed and $\left[\mathrm{Ca}^{2+}\right]_{i}=C_{0}$ throughout the cytoplasm. The cell was assumed to contain a total concentration, $B_{\text {tot }}$, of mobile calcium buffer, which included the calcium-free $\left(B_{0}\right)$ and calcium-bound $\left(B_{\mathrm{tol}}-B_{0}\right)$ forms. $B_{101}$ remained spatially uniform throughout the simulation because the buffer's diffusional mobility was assumed not to be influenced by its binding calcium. Under this assumption, calcium-bound and calcium-free forms can be considered together as a single species with respect to diffusion, which implies that the spatial distribution of total buffer is unaffected by calcium (Neher, 1986). This assumption excludes other interesting, and perhaps physiologically important, possibilities that are beyond the scope of this article.

\section{The rnobile calcium buffer}

The binding of calcium to the buffer followed the simple scheme

$$
\mathrm{Ca}+\text { Buffer } \underset{k_{\text {orr }}}{\stackrel{k_{\text {on }}}{\rightleftharpoons}} \mathrm{Ca} \cdot \text { Buffer, }
$$

where $K_{d}=k_{\text {off }} / k_{\text {on }}$. Initially, the mobile buffer was assumed to be in equilibrium with the spatially uniform free calcium, leading to a spatially uniform initial concentration $\left(B_{0}\right)$ of calcium-free buffer:

$$
B_{0}=B_{100}\left(\frac{K_{d}}{K_{d}+C_{0}}\right) \text {. }
$$

It is important to bear in mind that $B_{101}, B_{0}$, and $B$ all represent concentrations of mobile buffer. It is quite possible that cytoplasmic calcium-binding proteins also bind to fixed sites, creating an additional immobile fraction of buffer with a spatial distribution determined by the spatial distribution of fixed binding sites. However, the existence of immobile buffer would not influence the spatial uniformity of $B_{\text {tot }}$ unless calcium binding influenced the buffer's immobilization. As will be shown below (Fig. 2), an immobile fraction of buffer can slow the rise and fall in $\left[\mathrm{Ca}^{2+}\right]_{i}$ following the opening or closing of calcium channels, but does not influence the steady-state calcium concentration established around a particular set of open channels.

\section{The basic theory}

The extent to which calcium accumulates near a point of entry depends upon how rapidly it can diffuse away; the smaller its coefficient of diffusion $\left(D_{C_{a}}\right)$, the greater the accumulation. If diffusion is the only process operating, the rate at which the concentration changes $(\partial C / \partial t)$ at each point in space $(x, y, z)$ is proportional to the sum of the second spatial derivatives of the concentration, taken in the three cardinal directions (Crank, 1975):

$$
\frac{\partial C}{\partial t}=D_{\mathrm{Ca}}\left(\frac{\partial^{2} C}{\partial x^{2}}+\frac{\partial^{2} C}{\partial y^{2}}+\frac{\partial^{2} C}{\partial z^{2}}\right) .
$$

$C$ is usually defined as the total concentration of the solute, but to simplify the equations that follow, it is defined here as the change from the resting level:

$$
C=\left[\mathrm{Ca}^{2+}\right]_{i}-C_{0}
$$

Because subtracting a constant does not alter the derivatives in Equation 2 , the diffusion cquation also holds for this definition of $C$.

When a calcium buffer is present, additional terms must be included to represent the rate at which calcium associates and dissociates from the buffer. For the binding scheme shown above, the association rate is $k_{\mathrm{on}} B\left(C+C_{0}\right)$, and the dissociation rate is $k_{\mathrm{off}}\left(B_{\mathrm{tor}}-B\right)$. Using Equation 1 and the definition of $K_{d}$ to eliminate $B_{\text {tot }}$, the dissociation rate becomes $k_{\text {off }}\left(B_{0}-B\right)+k_{\mathrm{on}} B_{0} C_{0}$. Taking the difference between the association and dissociation rates, and rearranging terms, yields the net rate at which the buffer removes free calcium: $k_{\text {on }}\left[B C-\left(K_{d}+C_{0}\right)\left(B_{0}-B\right)\right]$. Subtracting this rate of calcium loss from the rate of accumulation due to diffusion alone (Eq. 2) gives the net rate of change of $C$ :

$$
\frac{\partial C}{\partial t}=D_{\mathrm{Ca}}\left(\frac{\partial^{2} C}{\partial x^{2}}+\frac{\partial^{2} C}{\partial y^{2}}+\frac{\partial^{2} C}{\partial z^{2}}\right)-k_{\mathrm{on}}\left[B C-\left(K_{d}+C_{0}\right)\left(B_{0}-B\right)\right] .
$$

A second equation, identical in form to Equation 3, describes the buffer's diffusion and binding of calcium:

$$
\frac{\partial B}{\partial t}=D_{\mathrm{Bu}}\left(\frac{\partial^{2} B}{\partial x^{2}}+\frac{\partial^{2} B}{\partial y^{2}}+\frac{\partial^{2} B}{\partial z^{2}}\right)-k_{\text {on }}\left[B C-\left(K_{d}+C_{0}\right)\left(B_{0}-B\right)\right\rfloor,
$$

where $D_{\mathrm{Bu}}$ is the diffusion coefficient for the mobile calcium buffer Steady-state solutions, $B_{\mathrm{ss}}$ and $C_{\mathrm{ss}}$, are found by setting $\partial B / \partial t=0$ and $\partial C / \partial t=0$. Equations 3 and 4 , along with appropriate initial and boundary conditions, comprise the model used for the simulations. The initial conditions were $C=0$ and $B=B_{0}$ throughout the cytoplasmic space. For the simulations of diffusion into a $10-\mu \mathrm{m}$-radius hemisphere, the boundary conditions were $C=0$ at all times at the hemispherical boundary; no flux of calcium across the flat (membrane) face except through one or more channels, each having a single-channel current of $I_{\mathrm{sc}}$; and no flux of buffer across any boundary. In the simulations of diffusion into the $2-\mu \mathrm{m}$-cube, the boundary conditions were changed such that $B$ was constrained to equal $B_{0}$ at the five cytoplasmic boundaries.

\section{Relationships among the parameters}

Nine constant parameters $\left(B_{\mathrm{to}}, B_{0}, D_{\mathrm{Bu}}, k_{\mathrm{on}}, k_{\mathrm{off}}, K_{d}, C_{0}, D_{\mathrm{Ca}}\right.$, and $\left.I_{\mathrm{sc}}\right)$ have been introduced to describe calcium and the mobile buffer (see Table 1). These constants, plus the location of each calcium channel in the membrane and the times at which each is open, determine $C$ and $B$ at each point in time and space. Two of these $\left(k_{\text {of }}\right.$ and $\left.B_{101}\right)$ do not appear in Equation 3 or 4 , or in the boundary conditions. $k_{\text {or }}$ is redundant because it is specified by $k_{\text {on }}$ and $K_{d \cdot} B_{\text {tot }}$ is not relevant because it is $B_{0}$, not $B_{101}$, that determines the amount of buffer available to capture incoming calcium.

Relationships between the remaining seven parameters allow further simplifications. $K_{d}$ and $C_{0}$ can be combined because they appear only as a sum in Equations 3 and 4. Three additional relationships, which can be verified by substitution into Equations 3 and 4, allow results corresponding to one set of parameters to be applied to other combi nations. If $\alpha$ is any positive number, then

Rule 1. To scale the time axis by $\alpha$ (i.e., make all changes occur $\alpha$ times faster), multiply $D_{\mathrm{Ca}}, D_{\mathrm{Bu}}, k_{\mathrm{on}}$, and $I_{\mathrm{sc}}$ by $\alpha$, while leaving $B_{0}, K_{d}$ and $C_{0}$ unchanged.

Rule 2. To scale (multiply) $B$ and $C$ by $\alpha$, multiply $B_{0}, C_{0}, K_{d}$, and $I_{\mathrm{sc}}$ by $\alpha$, divide $k_{\text {on }}$ by $\alpha$, and leave $D_{\mathrm{Ca}}$ and $D_{\mathrm{Bu}}$ unchanged.

Rule 3. Multiplying $D_{\mathrm{Bu}}$ and $k_{\mathrm{on}}$ by $\alpha$, dividing $B_{0}$ by $\alpha$, and leaving the other four parameters unchanged, causes $B_{\mathrm{ss}}$ to be divided by $\alpha$ without changing $C_{\text {ss. }}$.

If the properties of two buffers $\left(D_{\mathrm{Bu}}, B_{0}, k_{\mathrm{on}}, K_{d}\right)$ and $\left(D_{\mathrm{Bu}}^{\prime}, B_{0}^{\prime}, k_{\text {on }}^{\prime}\right.$ $K_{d}^{\prime}$ ) satisfy $K_{d}=K_{d,}^{\prime} k_{\mathrm{on}} B_{0}=k_{\mathrm{on}}^{\prime} B_{0}^{\prime}$, and $D_{\mathrm{Bu}} B_{0}=D_{\mathrm{Du}}^{\prime} B_{0}^{\prime}$, then Rule 3 can be applied with $\alpha=B_{0} / B_{0}^{\prime}$ to show that they produce the same $C_{s s}$. This relationship can be restated as the following important theorem:

Theorem 1 . For given values of $C_{0}, D_{\mathrm{Ca}}$, and $I_{\mathrm{sc}}$, the effect of a mobile calcium buffer on $C_{s s}$ is completely determined by three factors: (1) the mean time, $\tau_{c}=\left(k_{\mathrm{on}} B_{0}\right)^{-1}$, before a free-calcium ion is captured at the initial buffer concentration, (2) a factor, $R=B_{0} D_{\mathrm{Bu}}$, that determines how rapidly the calcium-free buffer is replenished near a site of calcium influx (see Theorem 2, below), and (3) $K_{d}$.

For a buffer that diffuses more slowly than calcium, the buffer's depletion is greater (by a factor of $\mathrm{D}_{(a}, \mathrm{D}_{B \nu}$ ) than the reduction in $\mathrm{C}_{s \mathrm{~s}}$ that it produces

Any buffer that is not infinitely mobile $\left(D_{\mathrm{Bu}}<\infty\right)$ becomes depleted [i.e., the concentration of calcium-free buffer $(B)$ decreases, and calciumbound buffer $\left(B_{\text {tor }}-B\right)$ increases] near a source of calcium, to an extent determined by how fast it can be replenished by diffusion. Let $C^{*}{ }_{s s}$ denote the value of $C_{\mathrm{ss}}$ that would occur without the mobile buffer. There is a simple relationship between the steady-state reduction in free calcium produced by the buffer $\left(C^{*}{ }_{\mathrm{ss}}-C_{\mathrm{ss}}\right)$ and the amount of buffer depletion $\left(B_{0}-B_{\mathrm{ss}}\right)$, which shows why a cell must produce a calcium buffer that is either highly mobile or highly concentrated to be effective near a source of calcium for which $C_{\text {ss }}^{*}>100 \mu \mathrm{M}$. It is easiest to begin with the special case of a hypothetical calcium buffer that diffuses as fast as free calcium $\left(D_{\mathrm{Bu}}=D_{\mathrm{C}}\right)$. Because calcium would then diffuse away from a source at the same rate whether or not it were bound to the buffer, the increase in total mobile calcium near the source in the 
presence of the buffer $\left(C_{\mathrm{ss}}+B_{0}-B_{\mathrm{ss}}\right)$ would equal the increase in mobile calcium without the buffer $\left(C_{\mathrm{ss}}^{*}\right)$, which implies that $C^{*}{ }_{\mathrm{ss}}-C_{\mathrm{ss}}=B_{0}$ $B_{\mathrm{ss}}$. Therefore, in the special case of $D_{\mathrm{Bu}}=D_{\mathrm{Ca}}$, the buffer would be depleted by the same amount as the reduction in free calcium that it produced.

In the more likely case of $D_{\mathrm{Bu}}<D_{\mathrm{Ca}}$, the buffer's depletion is greater bccause it is replenished more slowly. To convert this problem to the simple case discussed in the preceding paragraph, one applies Rule 3 with $\alpha=D_{\mathrm{Ca}} / D_{\mathrm{Bu}}$ to show that one can substitute a lower concentration $\left(B_{0}^{\prime}=B_{0} / \alpha\right.$ and $\left.B_{\mathrm{ss}}^{\prime}=B_{\mathrm{ss}} / \alpha\right)$ of a buffer that diffuses as fast as free calcium to produce the same $C_{\mathrm{ss}}$. This proves:

Theorem 2. At every point in space, the steady-state reduction in free calcium produced by a mobile buffer is proportional to the steady-state depletion of the buffer: $C^{*}-C_{\mathrm{ss}}=\left(B_{0}-B_{\mathrm{ss}}\right) D_{\mathrm{Bu}} / D_{\mathrm{Ca}}$. The maximum reduction in $C_{\mathrm{cs}}$ that can occur (when $B_{\mathrm{ss}}=0$ ) is $B_{0} D_{\mathrm{Bu}} / D_{\mathrm{Ca}}$

Therefore, for a calcium-binding protein that diffuses $1 / 10$ th as fast as calcium to reduce $C_{\mathrm{ss}}$ by $100 \mu \mathrm{M}$, its concentration would need to be $>1 \mathrm{~mm}$. Theorem 2 can be used to deduce $B_{0}$ from the buffer's effect on $C_{\mathrm{ss}}$ during a saturating calcium influx, if the ratio $D_{\mathrm{Bu}} / D_{\mathrm{Ca}}$ is known.

\section{Choice of standard parameter values}

A standard set of parameter values was used as the point of departure in simulations that varied one of the values. The buffer was assumed to have properties consistent with its presumed size $(28 \mathrm{kDa})$, and with previous experimental measurements in frog saccular hair cells (Roberts 1993). Based upon recent measurements of the mobility of globular proteins in axons (Popov and Poo, 1992), the value $D_{\mathrm{Bu}}=20 \mu \mathrm{m}^{2} \mathrm{sec}^{-}$ was chosen. The buffer's mean capture time for calcium, $\tau_{c}=3.3 \mu \mathrm{sec}$, was chosen to equal that of $500 \mu \mathrm{M}$ BAPTA [1,2-bis( $o$-aminophenyoxy)ethane- $N, N, N^{\prime}, N^{\prime}$-tetraacetic acid; see Roberts, 1993). The buffer's initial concentration $\left(B_{0}=2 \mathrm{mM}\right)$ was also taken from Roberts (1993) although the correct method of estimating $B_{0}$ from the data was not known at the time; a better estimate is derived below. The rate constant $\left(k_{\mathrm{on}}\right)$ for calcium binding to the buffer was then determined from the values of $\tau_{c}$ and $B_{0}\left(k_{\text {on }}=\left[\tau_{c}, B_{0}\right]^{-1}=1.5 \times 10^{8} \mathbf{M}^{-1} \mathrm{sec}^{-1}\right)$

For a protein, such as calbindin-D28k, that has multiple calciumhinding sites, $B_{0}$ represents the concentration of sites, which is greater than the concentration of the protein.

The native buffer's affinity for calcium has not been determined. The value of $K_{d}+C_{0}=1 \mu \mathrm{M}$ used for these simulations could correspond to $C_{0}=100 \mathrm{~nm}$ and $K_{d}=900 \mathrm{nM}$, or any other combination that adds to $1 \mu \mathrm{M}$. A value of $K_{d} \approx 1 \mu \mathrm{M}$ was chosen because a much higher affinity for calcium would cause a significant fraction of the buffer to be calcium bound at the resting calcium concentration (i.e., a large $B_{10 t}$ would be needed to attain a given $B_{0}$ ), and a much lower affinity would interfere with the buffer's ability to return $\left[\mathrm{Ca}^{2+}\right]_{i}$ rapidly to the resting level. The usual value was used for calcium's mobility in cytoplasm: $D_{\mathrm{Ca}}=200$ $\mu \mathrm{m}^{2} \sec ^{-1}$ (e.g., Nowycky and Pinter, 1993). The large single-channel current $\left(I_{\mathrm{sc}}=0.8 \mathrm{pA}\right)$ used in these simulations was based upon currentnoise measurements (Roberts et al., 1990). It corresponds to the current through a single calcium channel in a frog saccular hair cell at $-50 \mathrm{mV}$.

\section{Computer programs}

An electrochemical dynamics simulation program (AXON ENGINEER, Aeon Software, Eugene, OR) was used to calculate the time course of the rise and fall of $C$ in the hemisphere model. The volume was modeled as a series of 84 concentric hemispherical shells of three different thicknesses. The 30 innermost shells were each $3.33 \mathrm{~nm}$ thick, the next 27 shells were $33.3 \mathrm{~nm}$, and the remaining shells were $333 \mathrm{~nm}$ thick. The innermost shell contained the calcium source, which supplied calcium ions at a constant rate. The program used a variable time-step procedure that allowed accurate calculation of both the fast concentration changes close to the source and the slower changes far away (Figs. 2, 3). The program's output was checked against the solutions of two simple cases: an immobile buffer and an infinitely mobile buffer, for which analytical solutions are known (Crank, 1975; Neher, 1986).

This simulation program could not be applied to arrays of channels because symmetry was required to reduce three-dimensional diffusion to a one-dimensional problem. Instead, diffusion from an array of channels into a $2 \mu \mathrm{m}$ cube of cytoplasm was simulated using a spreadsheet (EXCEL, Microsoft, Inc., Bellevue, WA). The cytoplasmic space was divided into small cubical compartments, with two cells in the spreadsheet assigned to each compartment. One cell computed $C_{\mathrm{ss}}$, the other $B_{\mathrm{ss}}$. The values of $C_{\mathrm{ss}}$ and $B_{\mathrm{ss}}$ were calculated by iteration, using the finite difference method of Crank (1975). At each step, new estimates of $C_{\mathrm{ss}}$ and $B_{\mathrm{ss}}$ in a given compartment were calculated, based upon the previous values in the current compartment and the six neighboring compartments, to satisfy the steady-state condition of no net flux of calcium or buffer into the compartment:

$$
\begin{aligned}
& D_{\mathrm{Ca}} L \sum_{i}\left(C_{i, \mathrm{w}}-C_{w}\right)-L^{3} k_{\mathrm{on}}\left[B_{n} C_{w}-\left(K_{d}+C_{0}\right)\left(B_{0}-B_{w}\right)\right]=0, \\
& D_{\mathrm{Bu}} L \sum\left(B_{i, w}-B_{w}\right)-L^{3} k_{\mathrm{on}}\left[B_{s,} C_{w}-\left(K_{d}+C_{0}\right)\left(B_{0}-B_{s s}\right)\right]=0,
\end{aligned}
$$

where $C_{i . s s}$ and $B_{i . s s}$ are, respectively, the steady-state free-calcium and calcium-free buffer concentrations in the $i$ th neighbor of the current compartment, and $L$ is the length of one edge of the compartment. Equations 5 and 6 were solved for $C_{\mathrm{ss}}$ and $B_{\mathrm{ss}}$, and the two formulas were entered into the two cells corresponding to each cytoplasmic compartment:

$$
\begin{aligned}
& C_{\mathrm{ss}}=\frac{1}{6}\left(\sum C_{i, \mathrm{~s}}-\left(L^{2} k_{\mathrm{on}} / D_{\mathrm{ca}}\right)\left[B_{n} C_{\mathrm{s}}-\left(K_{d}+C_{0}\right)\left(B_{0}-B_{s \mathrm{~s}}\right)\right]\right), \\
& B_{\mathrm{s}}=\frac{1}{6}\left(\sum_{i} B_{i, w}-\left(L^{2} k_{\mathrm{on}} / D_{\mathrm{Bu}}\right)\left[B_{s,} C_{\mathrm{w}}-\left(K_{u}+C_{0}\right)\left(B_{0}-B_{\mathrm{ss}}\right)\right]\right) .
\end{aligned}
$$

The formulas in compartments along the borders were modified such that there was no diffusion across the cell membrane except at the point sources, which provided constant fluxes, and at the distant cytoplasmic border, where the concentrations were constant. After thousands of iterations, the values throughout the spreadsheet reached a stable pattern that satisfied the steady-state conditions at each point in space. All simulations were iterated until the maximum concentration change in any cell was $100 \mathrm{fM}$.

To reduce the number of compartments needed to simulate a $(2 \mu \mathrm{m})^{3}$ volume of cytoplasm, a nested series of spreadsheets was constructed, with each calculating concentrations in a smaller volume with higher spatial resolution. The largest volume consisted of a $13 \times 13 \times 13$ array of cubes, each $160 \mathrm{~nm}$ on a side. One face of the array corresponded to the membrane, with the channel array at its center. The second spreadsheet was a $13 \times 13 \times 13$ array of $80 \mathrm{~nm}$ cubes. The boundary values for the second and each subsequent spreadsheet were taken from the corresponding compartments in the previous spreadsheet. Subsequent spreadsheets were a $13 \times 13 \times 13$ array of $40 \mathrm{~nm}$ cubes, a $25 \times$ $25 \times 13$ array of $20 \mathrm{~nm}$ cubes, a $49 \times 49 \times 13$ array of $10 \mathrm{~nm}$ cubes, and a $97 \times 97 \times 6$ array of $5 \mathrm{~nm}$ cubes. Concentrations at the membrane were taken from the most superficial layer of the last spreadsheet

\section{Results}

\section{Diffusion from a point source into a large volume}

To investigate the importance of the buffer's diffusional mobility in avoiding its local depletion, I first considered a simple geometry, in which calcium diffused from a single point source in a flat membrane into a large hemispherical volume. Two sizes of current were considered: $I_{\mathrm{Ca}}=0.8 \mathrm{pA}$ (the current through a single hair cell calcium channel), or $I_{\mathrm{Ca}}=8 \mathrm{pA}$.

Figure 2 shows that a mobile buffer is more effective than a fixed buffer in suppressing the rise in $\left[\mathrm{Ca}^{2+}\right]_{i}$ and hastening its return to the resting level. With no buffer, $\left[\mathrm{Ca}^{2+}\right]_{i}$ at a distance of $55 \mathrm{~nm}$ from a point source of calcium rose to a steady level within a few hundred microseconds (Fig. $2 A$ ). With a mobile buffer, the rise was also initially rapid, but had a slow component associated with partial depletion of the calcium-free buffer (Fig. $2 C$ ), and reached a lower steady state. Setting $D_{\mathrm{Bu}}=0$ to immobilize the buffer (dashed curves) caused $\left[\mathrm{Ca}^{2+}\right]_{i}$ to follow an intermediate trajectory. For the first $\sim 50 \mu \mathrm{sec}$, the fixed and mobile buffers were equally effective. After that, the fixed buffer became locally saturated with calcium (Fig. $2 C$ ), causing $\left[\mathrm{Ca}^{2+}\right]_{i}$ to rise to the same level as without buffer. The mobile buffer also suffered substantial depletion $\left(25 \%\right.$ for $I_{\mathrm{Ca}}=0.8 \mathrm{pA} ; 98 \%$ for $I_{\mathrm{Ca}}=8 \mathrm{pA}$ ), but was still able to reduce the steady-state $\left[\mathrm{Ca}^{2+}\right]_{i}$ (by $80 \%$ and $30 \%$, respectively).

The large depletion of the mobile buffer $55 \mathrm{~nm}$ from an $8 \mathrm{pA}$ calcium source (Fig. $2 C$ ) is probably significant for frog saccular 

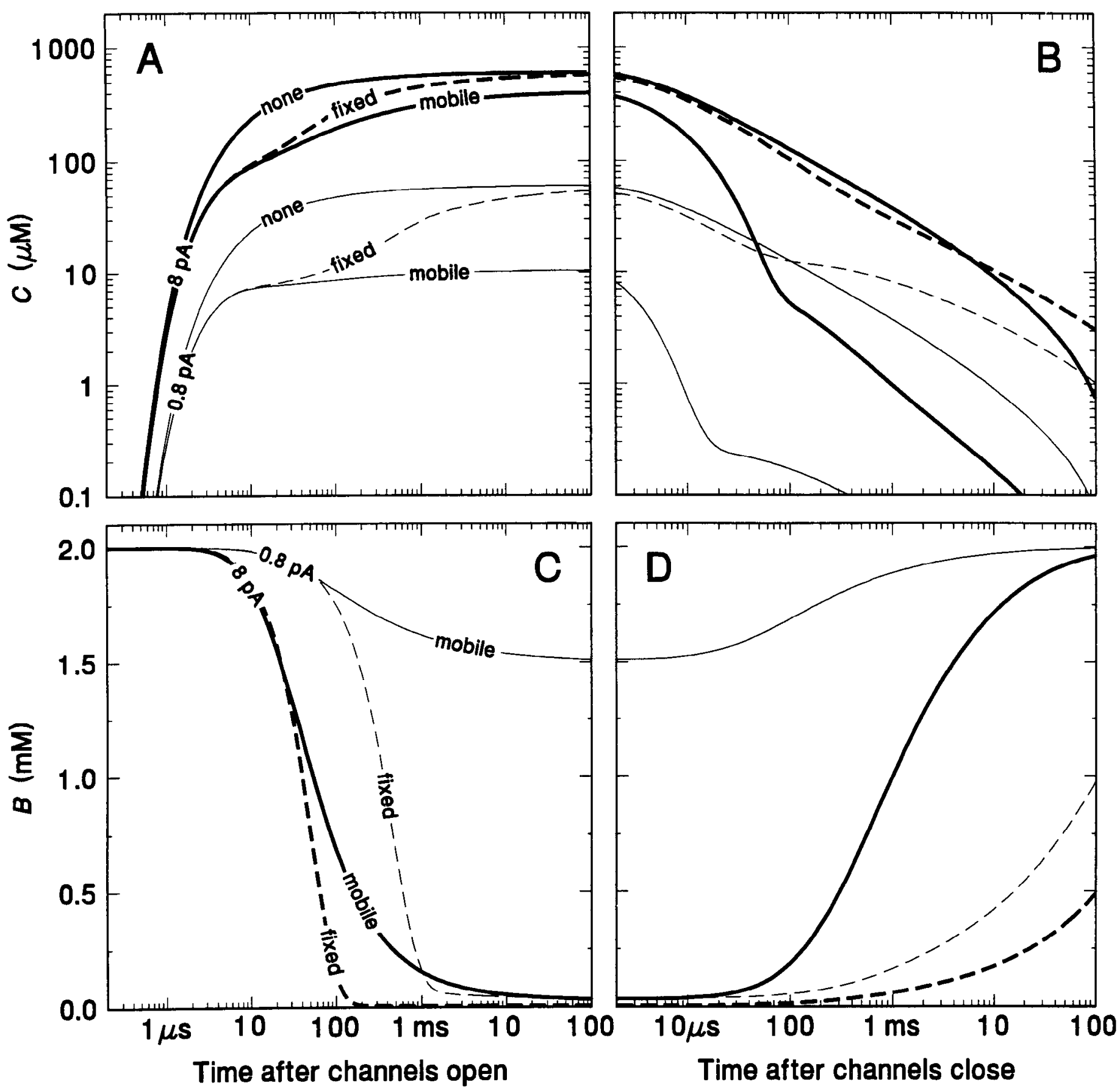

Figure 2. The time course of the rise $(A)$ and fall $(B)$ in free calcium (expressed as the change in $\left[\mathrm{Ca}^{2+}\right]_{i}$ from the resting level: $C=\left[\mathrm{Ca}^{2+}\right]_{i}-C_{0}$ ) at a distance of $55 \mathrm{~nm}$ from a point of calcium influx. Thin curves correspond to a single calcium channel $\left(I_{\mathrm{Ca}}=0.8 \mathrm{pA}\right)$; the thick curves, to $I_{\mathrm{Ca}}=$ $8 \mathrm{pA}$. The highest calcium concentrations occurred without any calcium buffer (labeled none), and the lowest with a mobile calcium buffer. A fixed calcium buffer (dashed lines) had an intermediate effect during the rise in $\mathrm{C}$, but did not lower the steady state (i.e., the curves for fixed buffer and no buffer converged at $t=100 \mathrm{msec}$ ). During the falling phase $(B),\left[\mathrm{Ca}^{2+}\right]_{i}$ returned more quickly to the resting level with a mobile buffer than with a fixed buffer or no buffer. The concentrations of the calcium-free forms of the fixed (dashed curves) and mobile (solid curves) buffers are shown in $C$ and $D$. Standard buffer properties were used for the mobile buffer (Table 1). The fixed buffer differed only in that $D_{\mathrm{Bu}}=0$.

hair cells, because a similar current density occurs within the hair cell's 250-300-nm-diameter channel clusters (i.e., 10 open calcium channels within a $110 \mathrm{~nm}$ diameter circle; see below). Figure 2 shows that $2 \mathrm{~mm}$ of mobile calcium-binding sites that diffuse at a rate appropriate for a $28 \mathrm{kDa}$ protein is not sufficient to avoid depletion when 10 calcium channels are open within a radius of $55 \mathrm{~nm}$.
The mobilc buffer's most dramatic cffects on the time coursc of calcium concentration changes occurred following the closure of the calcium channels (Fig. $2 B$ ), when it caused $\left[\mathrm{Ca}^{2+}\right]_{i}$ to decline $\sim 100$ times faster than without buffer. Starting from a level of $400 \mu \mathrm{M}\left(I_{\mathrm{Ca}}=8 \mathrm{pA}\right)$, the mobile buffer brought $\left[\mathrm{Ca}^{2+}\right]_{i}$ below $10 \mu \mathrm{M}$ in $100 \mu \mathrm{sec}$, and below $1 \mu \mathrm{M}$ in $1 \mathrm{msec}$. The fixed buffer had little effect on the rate of decline, and at times of 

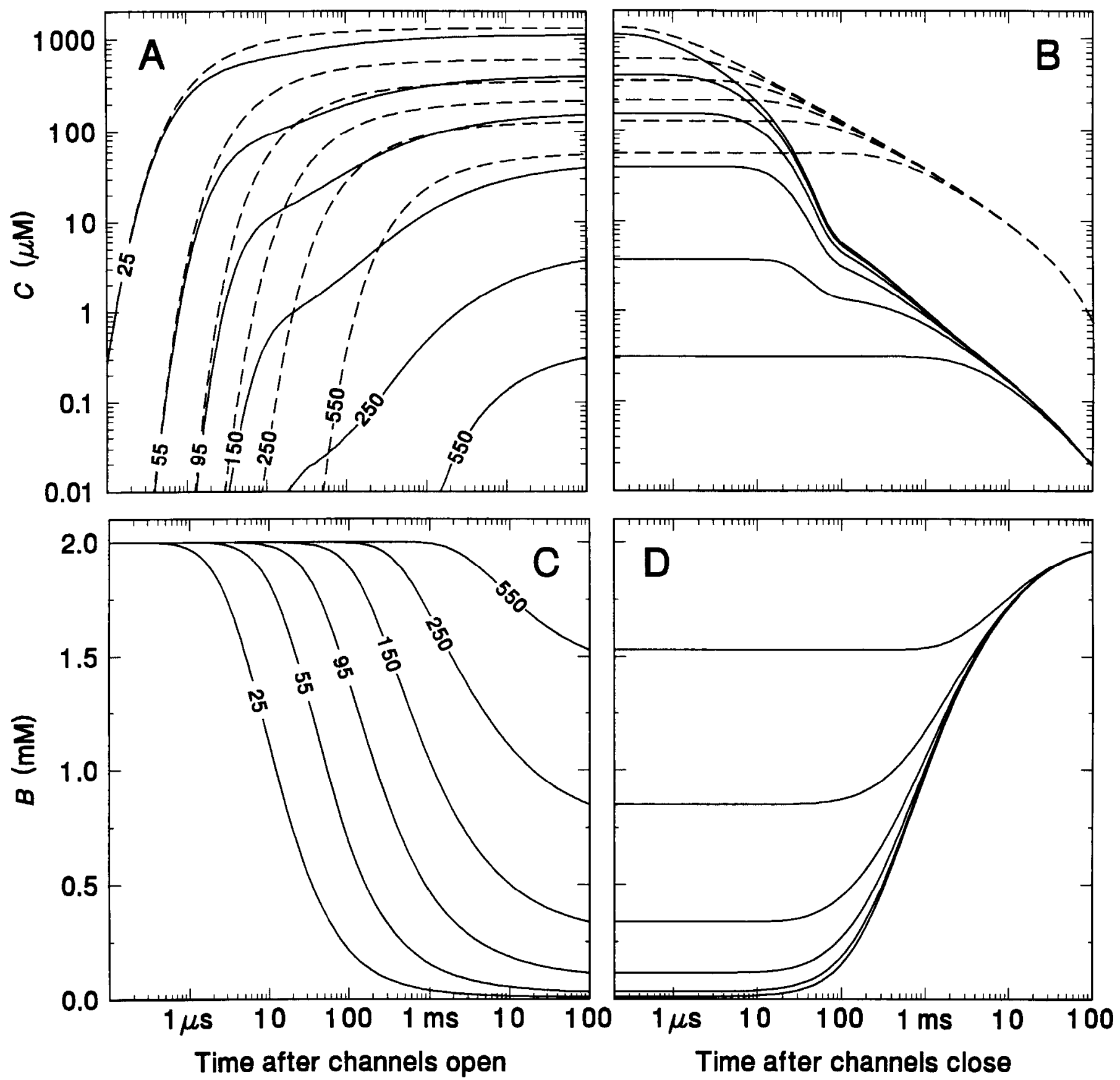

Figure 3. The time course of the rise $(A)$ and fall $(B)$ in free calcium, and the corresponding fall $(C)$ and rise $(D)$ in calcium-free buffer, at the distances indicated: $25,55,95,150,250$, and $550 \mathrm{~nm}$ from a point source of calcium $(8 \mathrm{pA})$. The solid curves were computed with the mobile calcium buffer, and the dashed curves without calcium buffer. Standard parameter values were used (Table 1).

$>10 \mathrm{msec}$ it actually maintained elevated calcium levels. Following closure of a single open channel $\left(I_{\mathrm{Ca}}=0.8 \mathrm{pA}\right)$, the mobile buffer was highly effective in returning $\left[\mathrm{Ca}^{2+}\right]_{i}$ to near the initial lcvel within $100 \mu \mathrm{sec}$.

Figure 3 shows the time course of the rise and fall in $\left[\mathrm{Ca}^{2+}\right]_{i}$ at various distances $(25-550 \mathrm{~nm})$ from a source $\left(I_{\mathrm{Ca}}=8 \mathrm{pA}\right)$, with and without a mobile buffer. The first feature to note is the wide range of time delays before the calcium concentration rose, from $<1 \mu \mathrm{sec}$ at $25 \mathrm{~nm}$ to $>1 \mathrm{msec}$ at $550 \mathrm{~nm}$. The delay represents the time required for calcium to diffuse a given distance, and illustrates the necessity for a close spatial association of calcium sources and receptors in fast processes. For the dis- tances most relevant to the calcium concentration within one of the hair cell's channel clusters $(<150 \mathrm{~nm}$ from the center; see below), the delays were very short $(<10 \mu \mathrm{sec})$, and not greatly influenced by the buffer.

Within $55 \mathrm{~nm}$ of the source in the presence of the mobile buffer, most of the change in $\left[\mathrm{Ca}^{2+}\right]_{i}$ was complete in $<100 \mu \mathrm{sec}$ after the calcium influx began (Fig. $3 A$ ) or ended (Fig. $3 B$ ). Based upon the $300 \mu \mathrm{sec}$ time constant of calcium tail currents (Roberts et al., 1990), this time is less than the average time that a calcium channel remains open. Therefore, the opening or closing of each nearby calcium channel in a cluster is expected to cause the local calcium concentration to change abruptly, then approach a steady 


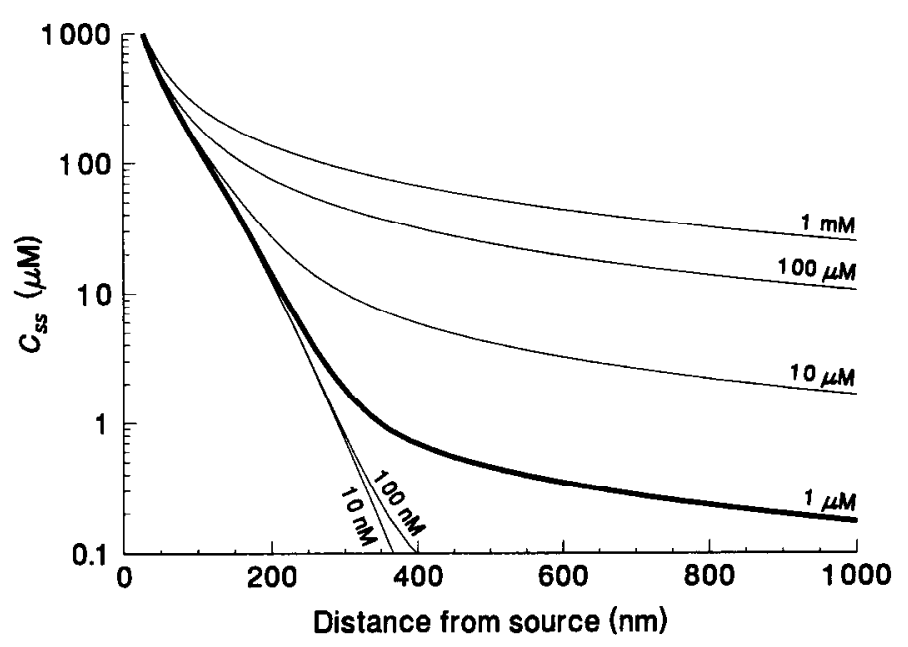

Figure 4. The effect of varying $K_{d}$ on the steady-state calcium concentration $\left(C_{\mathrm{ss}}\right)$ with $I_{\mathrm{Ca}}=8 \mathrm{pA}$. Curves correspond to $K_{d}+C_{0}=1 \mathrm{mM}$, $100 \mu \mathrm{M}, 10 \mu \mathrm{M}, 1 \mu \mathrm{M}, 100 \mathrm{nM}$, and $10 \mathrm{nM}$. The thick curve corresponds to the standard buffer $\left(K_{d}+C_{0}=1 \mu \mathrm{M}\right)$. Other parameters had the standard values (Table 1). Under physiological conditions, where $C_{0} \approx$ $100 \mathrm{nM}$, a value of $K_{u}+C_{0}=10 \mathrm{~nm}$ would not be possible.

state that persists until another nearby channel opens or closes. More distant sources can contribute to slower changes in $\left[\mathrm{Ca}^{2+}\right]_{i}$, but these changes are also smaller. Thus, to a first approxima-

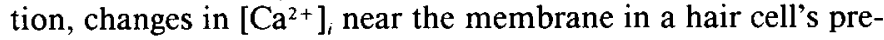
synaptic channel cluster occur in steps that correspond to each opening or closing of a nearby channel. This observation greatly simplifies thinking about the calcium landscape, because it means that the steady state associated with a particular pattern of open and closed channels approximates the instantaneous landscape much of the time. It is also important computationally, because the steady state is easier to calculate than the complete time course of the concentration change. In the steady state, mobile buffers, but not fixed buffers, can influence $\left[\mathrm{Ca}^{2+}\right]_{i}$ (Fig. 2).

The buffer's affinity for calcium is unimportant close to a calcium channel, where $\left[\mathrm{Ca}^{2+}\right]_{\mathrm{i}} \gg \mathrm{K}_{\mathrm{d}}$

It is reasonable to assume that a cytoplasmic calcium-binding protein that acts as a mobile calcium buffer would have a $K_{d}$ between $10 \mathrm{nM}$ and $100 \mu \mathrm{M}$. Figure 4 shows that varying $K_{d}$ within this range of values (i.e., holding $D_{\mathrm{Bu}}, B_{0}$, and $k_{\mathrm{on}}$ constant, while varying $k_{\text {off }}$ ) has little effect on the steady-state calcium concentration close to an $8 \mathrm{pA}$ calcium source. At distances $<100 \mathrm{~nm}$ from the source, changing $K_{d}$ had almost no effect on $C_{\mathrm{ss}}$, for values of $K_{d}+C_{0}<10 \mu \mathrm{M}$. Raising $K_{d}+C_{0}$ to $100 \mu \mathrm{M}$ caused at most a $50 \%$ increase in $C_{\mathrm{ss}}$ at distances $<100 \mathrm{~nm}$ from the source. The observation that $K_{d}$ has little influence on $C_{\text {ss }}$ close to a source is important for interpreting experimental data related to the cell's endogenous calcium buffer, for which $K_{d}$ is not known (Roberts, 1993).

The importance of a high concentration of a highly mobile buffer in resisting local depletion

To assess the importance of the buffer's concentration and diffusional mobility in counteracting its local depletion, I calculated the steady-state calcium and buffer concentrations near an 8 pA calcium source while (1) varying $B_{0}$ (Fig. 5, solid curves) between $0.2 \mathrm{~mm}$ and $20 \mathrm{~mm}$, and (2) varying $D_{\mathrm{Bu}}$ (Fig. 5, dashed curves) over a range that spanned the likely values for small
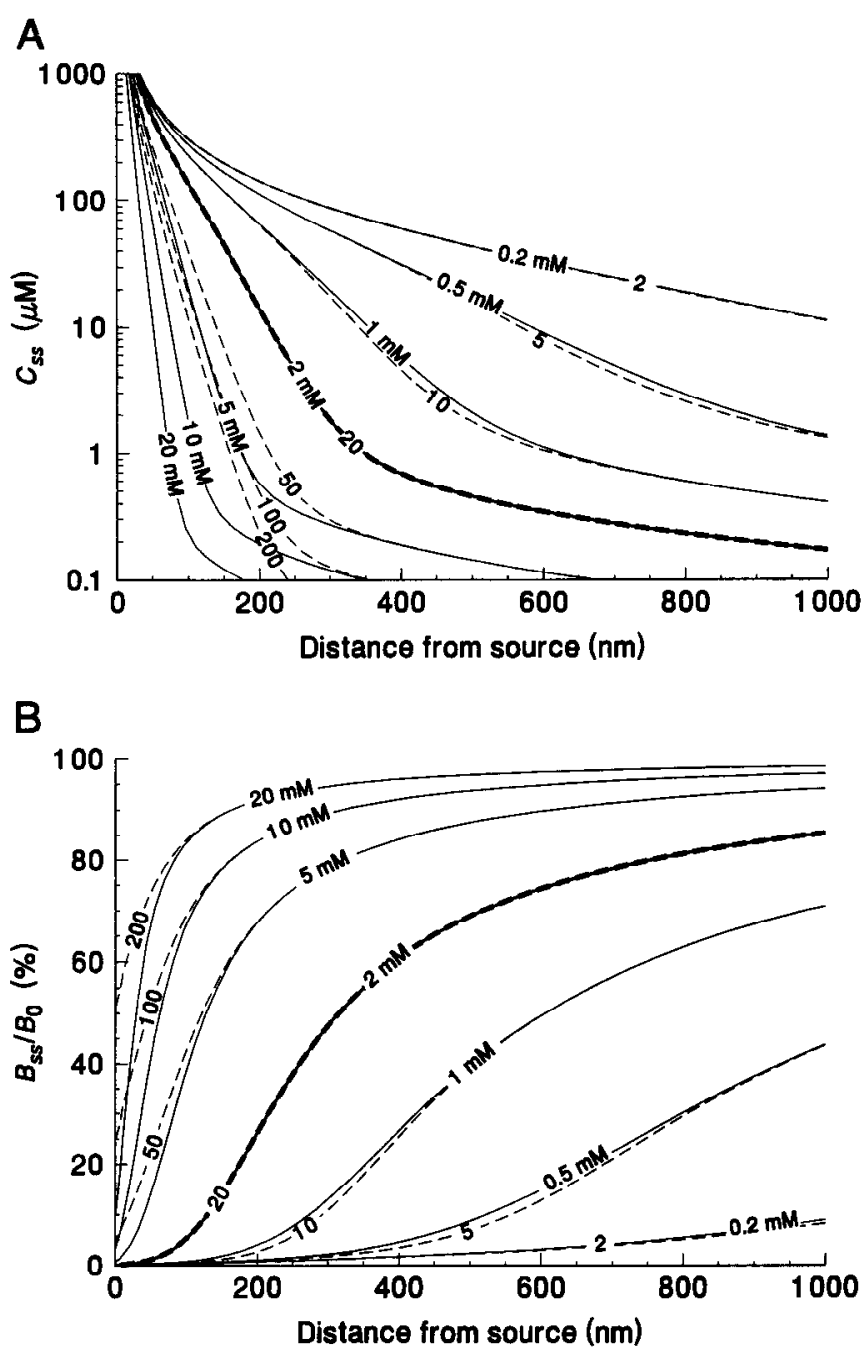

Figure 5. Comparison of the effects of buffer mobility $\left(D_{\mathrm{Bu}}\right)$ and concentration $\left(B_{0}\right)$ on $C_{\mathrm{ss}}$. Increasing either $D_{\mathrm{Bu}}$ or $B_{0}$ decreased free-calcium $(A)$ and increased calcium-free buffer $(B)$, expressed as a percentage of the initial concentration $\left(B_{\mathrm{ss}} / B_{0}\right)$. Dashed curves: $D_{\mathrm{Bu}}=2,5,10,20,50$, 100 , and $200 \mu \mathrm{m}^{2} \mathrm{sec}^{-1}$. Solid curves: $B_{0}=0.2,0.5,1,2,5,10$, and 20 mM. All other parameters had the standard values (Table 1). The thick curves correspond to the standard set.

proteins in cytoplasm. Reducing either $D_{\mathrm{Bu}}$ or $B_{0}$ below the standard values caused nearly complete depletion of the buffer for hundreds of nanometers from the source (Fig. $5 B$ ). Increasing either $D_{\mathrm{B}}$ or $B_{0}$ above the standard values resulted in less depletion of buffer near the source (Fig. $5 B$ ), and therefore a steeper decline in $\left[\mathrm{Ca}^{2+}\right]_{i}$ with distance from the source (Fig. $5 A$ ). Therefore, both $D_{\mathrm{Bu}}$ and $B_{0}$ contribute to the buffer's effectiveness. Under conditions where the buffer was highly depleted near the source (i.e., when $D_{\mathrm{Bu}}$ or $B_{0}$ was reduced below the standard value), their effects were nearly identical (i.e., dividing $B_{0}$ by a factor of 2,4 , or 10 had the same effect on $\left[\mathrm{Ca}^{2+}\right]_{i}$ as dividing $D_{\mathrm{Bu}}$ by the same factor; Fig. $5 A$; see Theorem 2, above). Under conditions where the buffer was not completely depleted near the source (i.e., when $D_{\mathrm{Bu}}$ or $B_{0}$ was raised above the standard value), increasing $B_{0}$ was more effective than increasing $D_{\mathrm{Bu}}$ (i.e., multiplying $B_{0}$ by $2.5,5$, or 10 caused a steeper decline in $\left[\mathrm{Ca}^{2+}\right]_{i}$ than multiplying $D_{\mathrm{Bu}}$ by the same factor; Fig. $5 \mathrm{~A}$ ).

The different effects of changing $B_{0}$ or $D_{\mathrm{Bu}}$, depending upon the extent to which the buffer is locally depleted, will be useful 

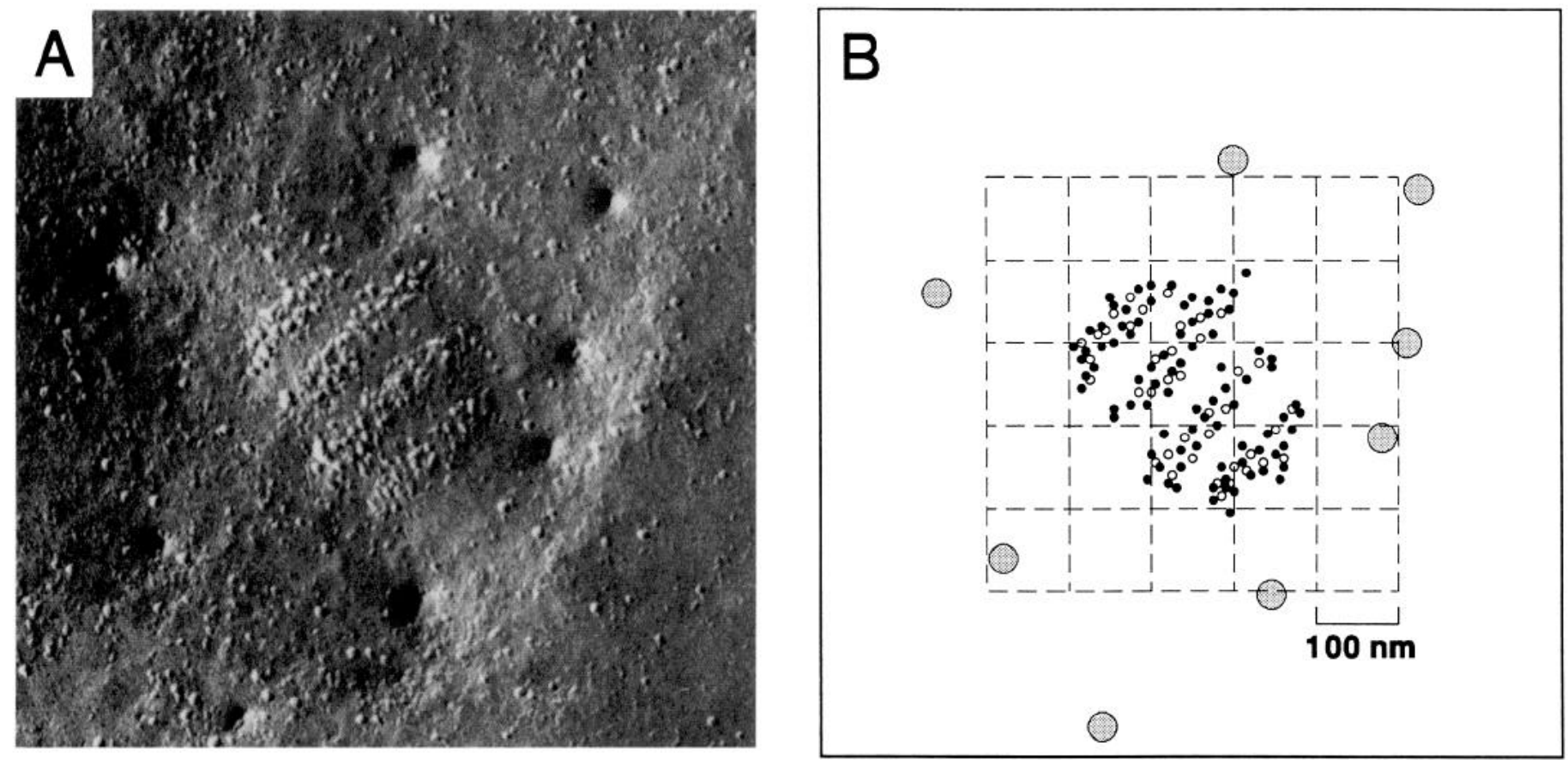

Figure 6. The prototypic presynaptic channel cluster used in the simulations shown in Figures 7-11. A, A freeze-fracture electron micrograph of a presynaptic particle array on a frog saccular hair cell. Four rows of particles are surrounded by a few larger depressions. Each particle in the four rows was assumed to correspond to an individual ion channel. $B$, The channel identities, which were assigned to obtain a ratio of 85 calcium channels $/ 40 \mathrm{~K}_{\mathrm{Ca}}$ channels, using an algorithm that maximally interspersed the two types. Open circles correspond to $\mathrm{K}_{\mathrm{Ca}}$ channels, and the solid circles to calcium channels. Large stippled circles correspond to the depressions in $A$. The dashed grid corresponds to the grid in Figure 7 , and shows the $500 \times 500 \mathrm{~nm}$ area beneath which the simulated calcium concentration is shown in Figures $7,8,10$, and $11 . A$ and $B$ are shown at the same scale.

later in estimating these two factors from experimental data. In the terminology used in Theorem 1 , the mean capture time, $\tau_{c}$ $=\left(k_{\mathrm{on}} B_{0}\right)^{-1}$, which depends upon $B_{0}$ but not $D_{\mathrm{Bu}}$, is most important near a calcium source under conditions that do not deplete the buffer. The other factor, $R=D_{\mathrm{Bu}} B_{0}$, which is influenced equally by changes in either $D_{\mathrm{Bu}}$ or $B_{0}$, is most important far from the source and/or when the buffer is highly depleted at the source. In the limiting case of a very small calcium current, when buffer depletion does not occur, $R$ is not important and $\tau_{c}$ alone determines the buffer's effect on $\left[\mathrm{Ca}^{2+}\right]_{i}$ (Neher, 1986). Figure 5 illustrates that, in the opposite extreme when the buffer is completely depleted at the source (as would occur during a large calcium current, or with low buffer concentration or low buffer mobility), changing $\tau_{c}$ while holding $R$ constant has no effect on $C_{\text {ss }}$ (i.e., the three pairs of curves corresponding to dividing $R$ by factors of 2,4 , or 10 superimpose, even though the two curves in each pair have different values of $\tau_{c}$ ). Therefore, information about $\tau_{c}$ and $R$ can be obtained by observing the buffer's effect during, respectively, small and large calcium currents.

\section{A model of buffered calcium diffusion near the hair cell's presynaptic channel array}

To see how the calcium concentration varied within an array of channels, I chose a realistic spatial arrangement of channels in one of a frog saccular hair cell's $\sim 20$ presynaptic clusters, and computed the steady-state calcium concentration with some of the channels open. Within $100 \mathrm{~nm}$ of one or more open calcium channels, this steady state is approached during the average time that individual channels remain open ( $300 \mu \mathrm{sec}$; see Fig. 3), and is therefore a useful approximation to the in- stantaneous calcium concentration. Slightly farther $(>500 \mathrm{~nm})$ from the channels, where a steady state is achieved only after tens or hundreds of milliseconds (Fig. 3), the calculations are relevant only for maintained calcium currents. Figures 7-11 show the results of such steady-state simulations for a variety of conditions.

First, it was necessary to define the structure of a "typical" presynaptic site, including the precise location of each calcium channel. To compare the simulations to previous physiological measurements (Roberts et al., 1990; Roberts, 1993), it was also necessary to assign positions to the calcium-activated potassium $\left(\mathrm{K}_{\mathrm{Ca}}\right)$ channels that had served as the calcium sensors in experiments that inferred the local $\left[\mathrm{Ca}^{2+}\right]_{i}$ within the channel clusters from the percent activation of the whole-cell $\mathrm{K}_{\mathrm{Ca}}$ current, while replacing the cell's endogenous mobile calcium buffer with various exogenous calcium buffers.

Channel locations were assigned according to the hypothesis that each intramembrane particle in the presynaptic array (Hama, 1980) corresponds to a channel (Jacobs and Hudspeth, 1990; Roberts et al., 1990). Freeze-fracture electron micrographs reveal a characteristic pattern of parallel rows of large intramembrane particles at each presynaptic site (Fig. 6 $\mathrm{A}$ ). Similar presynaptic particle arrays have been observed in many types of cells, and are thought to correspond to clusters of calcium channels (Pumplin et al., 1981; see also Adler et al., 1991; Cohen et al., 1991; Robitaille and Charlton, 1992). However, both calcium channels and $\mathrm{K}_{\mathrm{Ca}}$ channels are present in the presynaptic arrays of hair cells (Roberts et al., 1990, 1991); $\mathrm{K}_{\mathrm{Ca}}$ channels are closely associated with presynaptic calcium channels at other synapses as well (Stockbridge and Ross, 1984; Lancaster and Nicoll, 1987; Robitaille and Charlton, 1992; Callaway et al., 


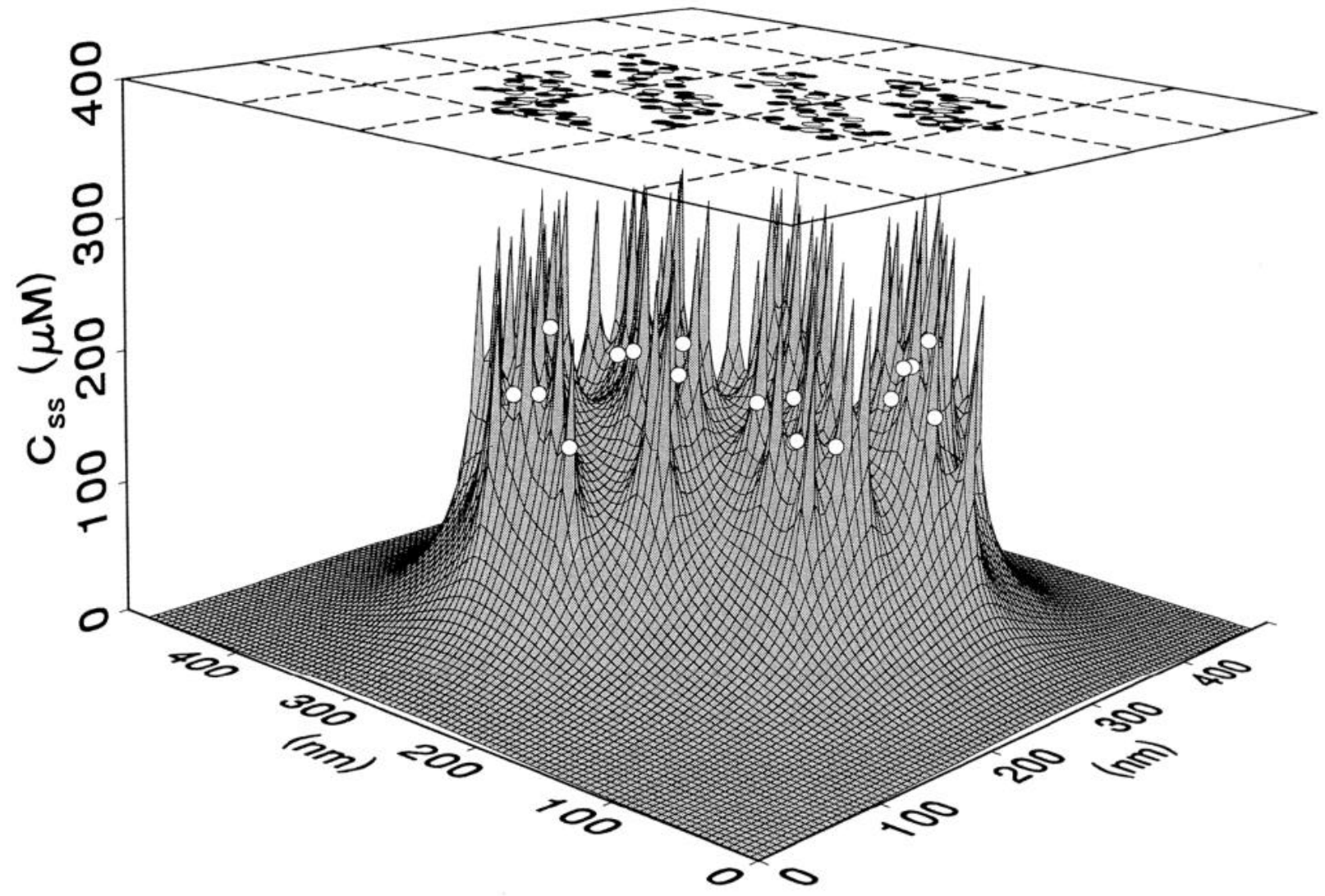

Figure 7. The steady-state calcium concentration $\left(C_{\mathrm{ss}}\right)$ within $5 \mathrm{~nm}$ of the membrane (i.e., in the outermost $97 \times 97$ array of $5 \mathrm{~nm}$ cubes) during a constant $8 \mathrm{pA}$ calcium current. In this simulation, each of the 85 calcium channels was assigned a current of $0.094 \mathrm{pA}$, which is $\sim 12 \%$ of the current through a single calcium channel. The simulation thus shows the "time-averaged" calcium landscape when an average of 10 calcium channels in the cluster are open. The locations of the calcium channels (solid circles) and $\mathrm{K}_{\mathrm{Ca}}$ channels (open circles) are projected on the plane above. The open circles below mark the position of the $\mathrm{K}_{\mathrm{Ca}}$ channels on the calcium landscape to show the calcium concentration at the $\mathrm{K}_{\mathrm{Ca}}$ channel sites.

1993). Rather than attempting to idealize the "typical" geometry, I selected one average-sized array to serve as the prototype, and measured the $\mathrm{x}, \mathrm{y}$-coordinates of the 125 large intramembrane particles (Fig. $6 B$ ). Since there was no way to distinguish calcium channels from $\mathrm{K}_{\mathrm{Ca}}$ channels, identities were assigned by an algorithm that maximally interspersed the two types (i.e., assumed that channels of the same type repelled each other and attracted the opposite type, then assigned identities to minimize the repulsion). All simulations used the channel ratio determined from physiological experiments $\left(85\right.$ calcium $/ 40 \mathrm{~K}_{\mathrm{Ca}_{\mathrm{a}}}$ channels; Roberts et al., 1990). There were some ambiguities in delineating the borders of the particle array, and in deciding whether a given "particle" in the photograph represented one channel or two closely spaced channels. The identifications therefore represent, to some extent, an idealization based upon the principle that presynaptic channels tend to occur in rows (see Augustine et al., 1985).

Two types of simulations were performed to show the predicted calcium profile in and around the channel cluster when the membrane potential is held depolarized to a level that opens an average of 10 calcium channels in the array $(12 \%$ of the 85 channels, $I_{\mathrm{Ca}}=8 \mathrm{pA}, V_{m} \approx-50 \mathrm{mV}$; Roberts et al., 1990). Even though the whole-cell calcium and $\mathrm{K}_{\mathrm{Ca}}$ currents at this membrane potential quickly reach stable levels that last for hundreds of milliseconds, the calcium landscape within each channel cluster continues to change rapidly during this time, as individual calcium channels flicker open and shut. The opening of each channel raises a spire of calcium above it that rapidly approaches a steady state that persists until the channel closes a few hundred microseconds later. An easy way to obtain an instantaneous picture of the calcium landscape is therefore to freeze a particular configuration of open channels, and compute the steady-state $\left[\mathrm{Ca}^{2+}\right]_{i}$ around them. Although this "frozen" landscape does not give an entirely accurate instantaneous picture, because one or more spires may be rising or falling at any instant in time, it shows the spatial variation in $\left[\mathrm{Ca}^{2+}\right]_{i}$ that is present within the cluster. For some purposes, a time-averaged calcium landscape is more informative than the instantaneous picture. "Time-averaged" simulations were performed by assigning the 85 calcium channels equal fractions of the total 8 pA current ( $0.094 \mathrm{pA}$ each). Like the "frozen" simulation, this "time-averaged" simulation represents an approximation to the true calcium landscape. However, it will become evident that both approximations are excellent during maintained depolarizations (see below).

Figure 7 shows the "time-averaged" calcium topography with the standard mobile buffer, in which height represents the steadystate calcium concentration close to the membrane (i.e., in the outermost layer of $5 \mathrm{~nm}$ cubes; see Materials and Methods). The array of calcium channels (solid circles) and $\mathrm{K}_{\mathrm{Ca}}$ channels (open circles) is projected onto a plane above, and the $\mathrm{K}_{\mathrm{Ca}}$ channels onto the calcium landscape below to show the approximate 

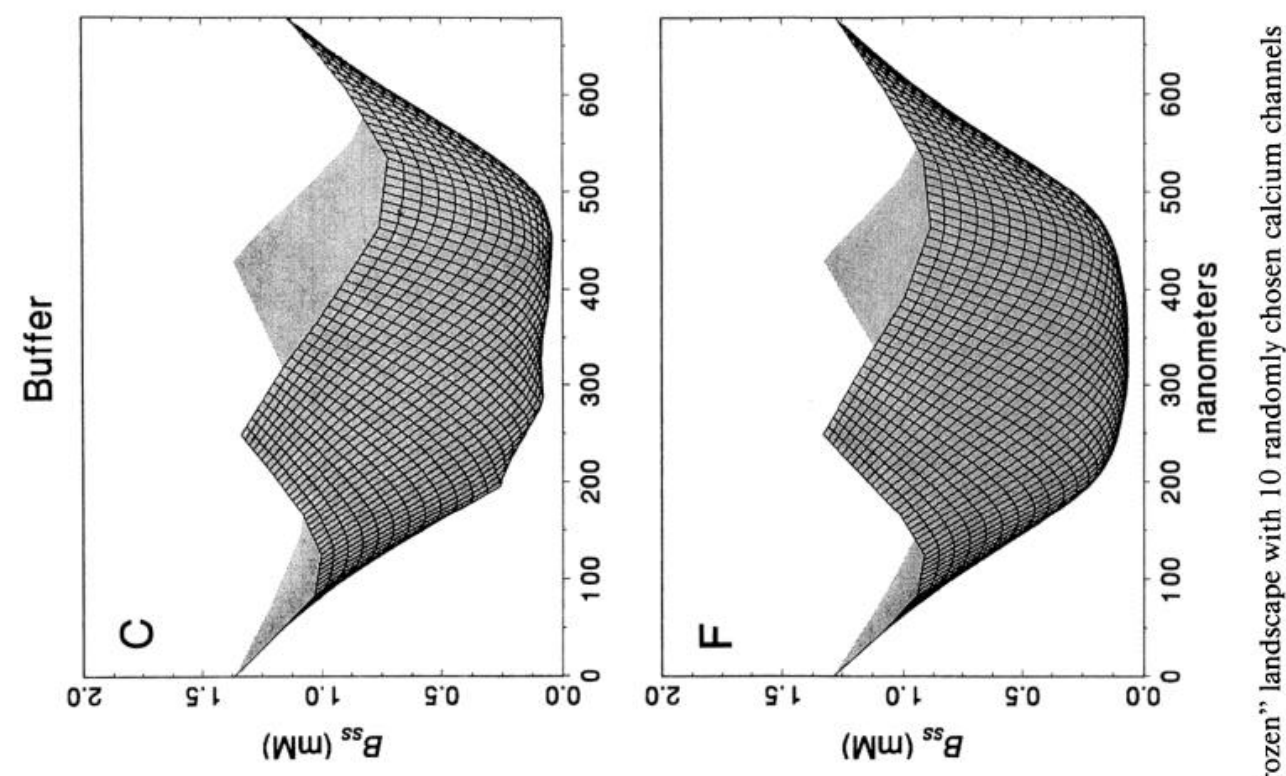

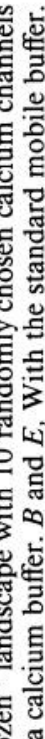

章苛


焉

U०

记

बष त्ष

$\infty<\frac{1}{0}$

叫

ड़े

उั

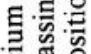

을 는

ज]

흐른 눈

on 흠

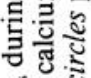

$\infty^{2}$ 등

ปี

uे ख्ये

중

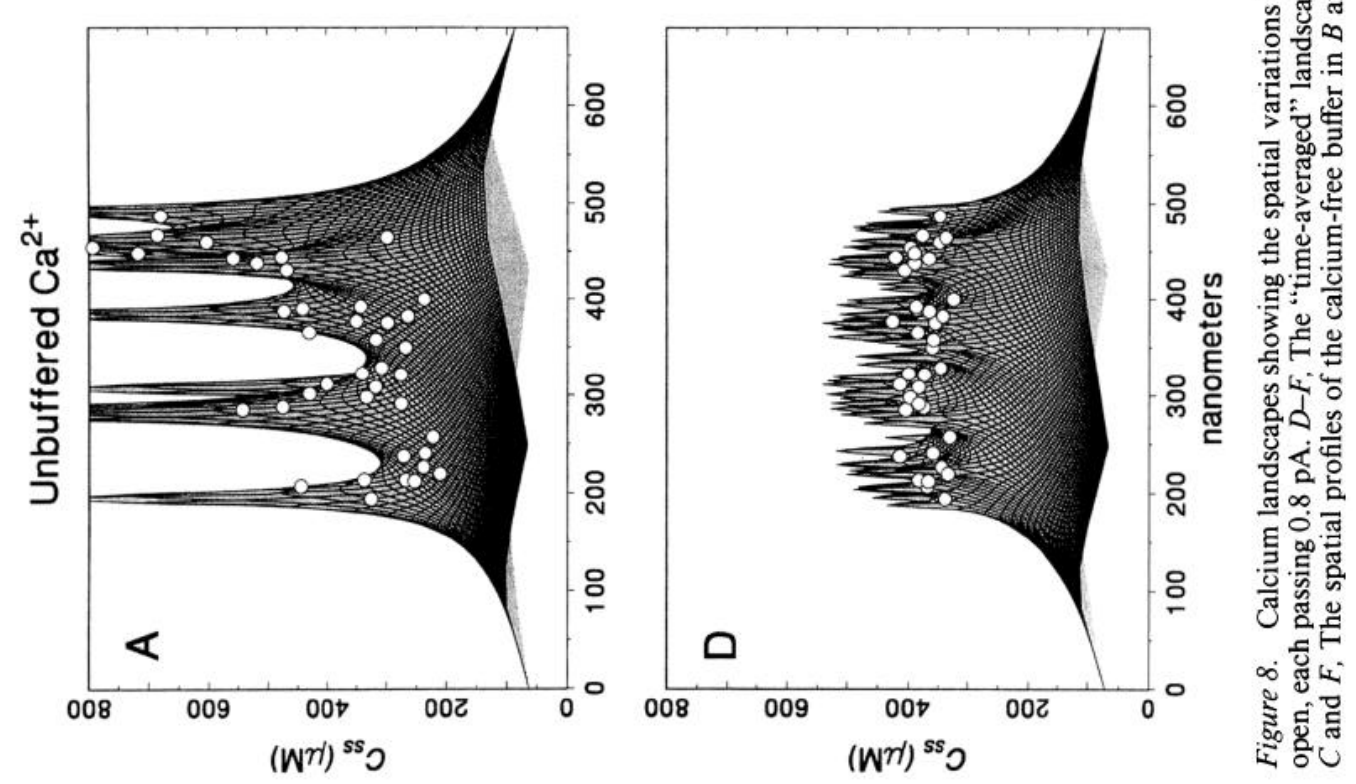




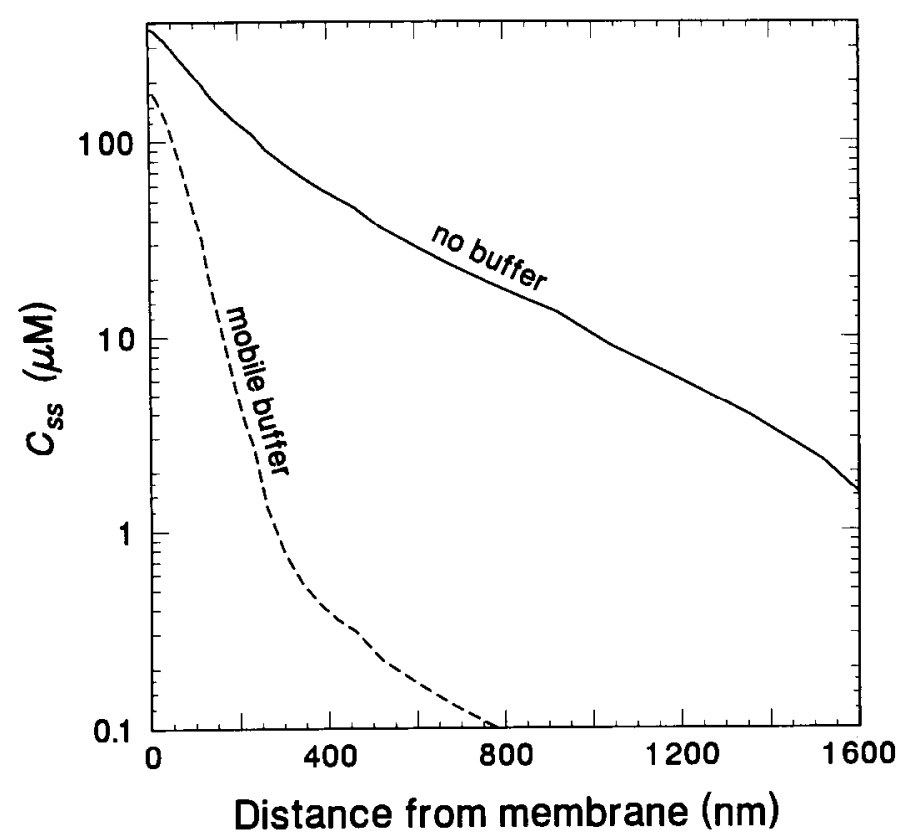

Figure 9. The decline in $C_{\mathrm{ss}}$ with distance into the cell (perpendicular to the membrane), along a line that intersected the membrane at the center of the channel cluster [same simulations as Figure $8 D$ (without buffer) and $E$ (with the standard buffer)]. The small discontinuities in slope are artifacts at the borders of the nested spreadsheets (see Materials and Methods).

average calcium concentration that each $\mathrm{K}_{\mathrm{Ca}}$ channel would experience when each calcium channel is open $12 \%$ of the time. Figure $8 E$ shows the same landscape viewed from the side.

The mobile buffer greatly constricted the region of high $\left[\mathrm{Ca}^{2+}\right]_{i}$. Without the buffer, $C_{\mathrm{ss}}$ was $>50 \mu \mathrm{M}$ at the edge of the $500 \mathrm{~nm}$ $\times 500 \mathrm{~nm}$ region shown (Fig. $8 A, D$ ). With the buffer, $C_{\mathrm{ss}}$ fell precipitously to near zero at the edge of the cluster (Fig. $8 B, E$ ).

As in Figures 2 and 3, there was a nearly complete local depletion of the buffer (Fig. 8C,F). Two additional significant features of the buffer depletion are also apparent. First, $B_{\mathrm{ss}}$ varied smoothly with position, as compared to the jagged profile of $C_{\text {ss }}$. Second, there was little difference between the "frozen" (Fig. $8 C$ ) and "time-averaged" (Fig. $8 F$ ) buffer profiles. Therefore, during a maintained depolarization that opens an average of 10 calcium channels in the cluster, the buffer profile does not depend grcatly on which particular channels are open, and therefore does not change significantly as individual channels open and close. The fact that $B_{\mathrm{ss}}$ is nearly constant in time during a constant calcium current removes the nonlinearity associated with buffer depletion from the diffusion equations (Eqs. 3, 4), leaving a linear relationship between $I_{\mathrm{Ca}}$ and $C_{\mathrm{ss}}$. This linearity implies that the "time-averaged" $C_{\mathrm{ss}}$, which was calculated by assigning each calcium channel its average current, is the same as the true average of $C$ that would be obtained over times long enough to include the opening and closing of many calcium channels. The constancy of $B_{\mathrm{ss}}$ also means that changes in $\left[\mathrm{Ca}^{2+}\right]_{i}$ following the opening or closing of each channel occur even more rapidly than is seen in Figure 2, in which the slow depletion of buffer created the slow component of the change in $\left[\mathrm{Ca}^{2+}\right]_{i}$. With a constant buffer profile, the slow components disappear, causing $\left[\mathrm{Ca}^{2+}\right]$, to step more abruptly. Thus, the "frozen" and "time-averaged" computations are excellent approximations to the instantaneous and time-averaged calcium profiles during a maintained depolarization that establishes a nearly constant buffer profile.

The buffer's effect on calcium-activated potassium channel activation was assessed by measuring the mean calcium concentration at the $40 \mathrm{~K}_{\mathrm{Ca}}$ channel sites (open circles in Fig. 8). The values were (mean $\pm \mathrm{SD}$ ), for time-averaged with buffer (Fig. $8 E$ ), $188 \pm 24 \mu \mathrm{M}$; time-averaged without buffer (Fig. $8 D$ ), $374 \pm 27 \mu \mathrm{M}$; instantaneous with buffer (Fig. 8B), $209 \pm 143$ $\mu \mathrm{M}$; instantaneous without buffer (Fig. 8A), $393 \pm 150 \mu \mathrm{M}$. An additional simulation (time-averaged with buffer) was carried out with $I_{\mathrm{Ca}}=8.1 \mathrm{pA}$, which produced a mean calcium concentration of $192 \pm 24 \mu \mathrm{M}$. From the difference between the averages when $I_{\mathrm{Ca}}=8.1 \mathrm{pA}$ and $I_{\mathrm{Ca}}=8 \mathrm{pA}$, one can calculate the steepness of the increase in $\left[\mathrm{Ca}^{2+}\right]_{i}$ with calcium current: 4.1 $\mu \mathrm{M} / 0.1 \mathrm{pA}=41 \mu \mathrm{M} / \mathrm{pA}$. By comparing this value to the slope without buffer (slope $=374 \mu \mathrm{M} / 8 \mathrm{pA}=47 \mu \mathrm{M} / \mathrm{pA}$; unbuffered calcium accumulation is proportional to $I_{\mathrm{Ca}}$; Crank, 1975), one can determine the buffer's effectiveness at maintaining the low $\left[\mathrm{Ca}^{2+}\right]_{i}$ as $I_{\mathrm{Ca}}$ is increased above $8 \mathrm{pA}$. That the slope with buffer was only $13 \%$ less than without buffer shows that, even though the $2 \mathrm{~mm}$ standard buffer reduced calcium accumulation by $50 \%$ during an $8 \mathrm{pA}$ calcium current, it was almost completely exhausted in the process, and had little effect on the increase in $\left[\mathrm{Ca}^{2+}\right]_{i}$ caused by additional calcium influx.

The mobile buffer also caused $C_{\mathrm{ss}}$ to decline steeply with distance into the cell. Figure 9 shows the decline with distance perpendicular to the cell surface with and without the mobile buffer.

\section{Possible effects of the presynaptic body}

Hair cells, like retinal photoreceptors and some pineal neurons, have a large presynaptic body associated with each afferent synapse. A monoclonal antibody raised against mouse retina (B16; Balkema, 1991) labels the synaptic ribbons in photoreceptors of all vertebrates examined, and has been used to purify one component, an $88 \mathrm{kDa}$ protein. B16 also labels the presynaptic bodies of hair cells (Roberts and Hagedorn, 1992). In frog saccular hair cells, the $\sim 400$-nm-diameter body is spherical or ovoid, and is located in the cytoplasm adjacent to the channel array, separated from the membrane by a distance approximately equal to the diameter of a synaptic vesicle $(\sim 40 \mathrm{~nm}$; Gleisner et al., 1973; Hama and Saito, 1977; Jacobs and Hudspeth, 1990; Roberts et al., 1990). Given the large size and close association of the synaptic body with the channel array, it is important to consider how it could influence calcium diffusion.

The spatial relationship between the body and the plasma membrane may be more complex than simply a sphere next to a plane. In transmission and freeze-fracture electron micrographs (Gleisner et al., 1973; Hama and Saito, 1977; Hama, 1980; Jacobs and Hudspeth, 1990; Roberts et al., 1990), the membrane often appears to curve slightly around the body, resulting in a relatively uniform spacing between the two. To incorporate this relationship into the diffusion model, the body was represented as a truncated sphere, with the flat face parallel to the plasma membrane at a distance of $40 \mathrm{~nm}$. The area of close apposition was a 250 -nm-diameter circle.

Because the body is neither surrounded by nor appears to contain membranous structures, one likely possibility is that it does not impede diffusion of calcium or buffer, and thus has no effect on $\left[\mathrm{Ca}^{2+}\right]_{i}$. To test other possibilities, simulations were performed making two assumptions that represent opposite extremes. In Figure 10, $A$ and $B$ were computed assuming that 

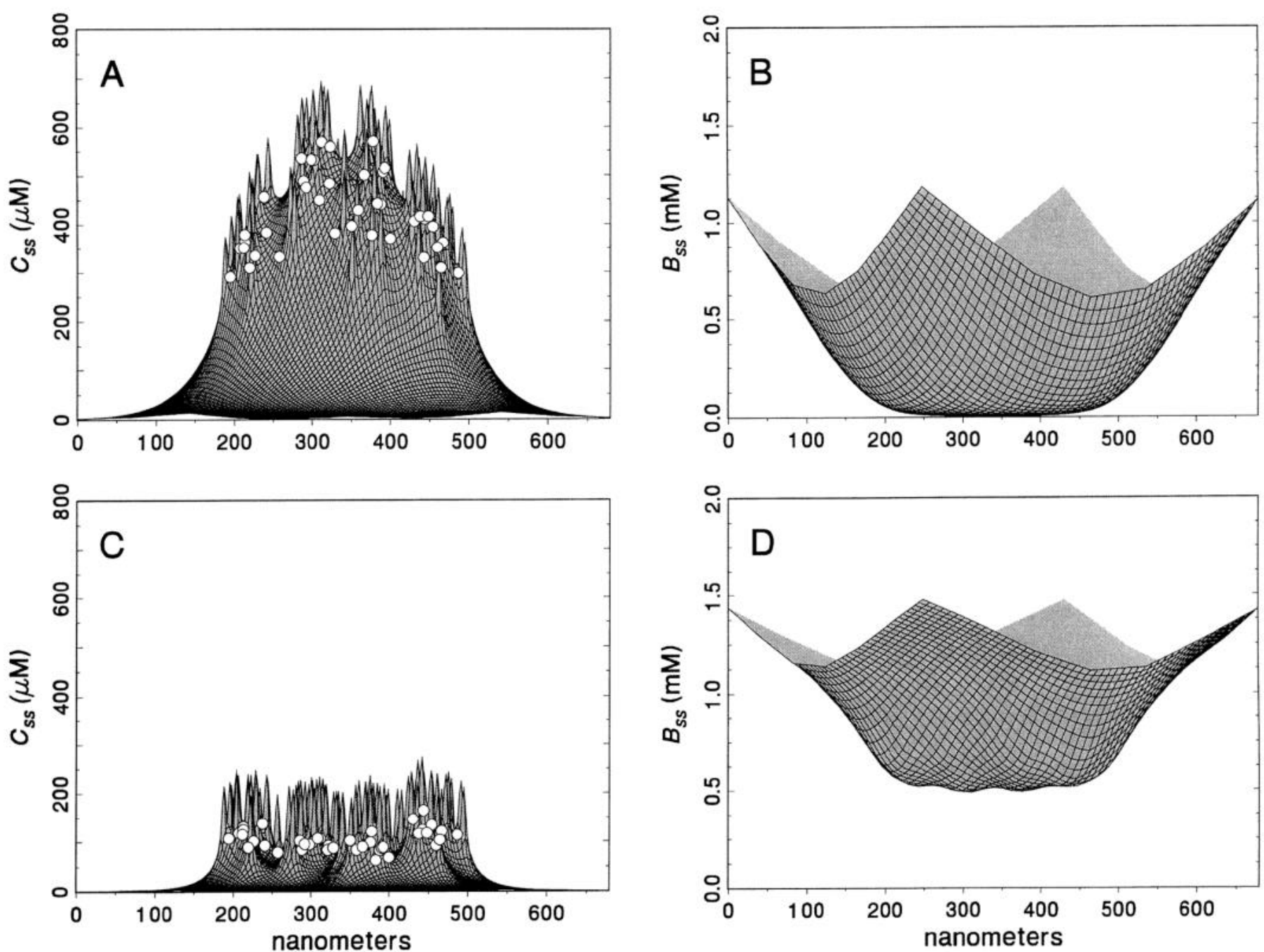

Figure 10. Possible effects of the presynaptic body on $C_{\mathrm{ss}}$ and $B_{\mathrm{ss}}$ near the membrane. The body was represented as a sphere, $400 \mathrm{~nm}$ in diameter, with a thin slice removed to create a $250-\mathrm{nm}$-diameter flat face that was located parallel to the cell membrane at a distance of $40 \mathrm{~nm}$. Two extreme cases are shown. In $A$ and $B$, the body was assumed to form a barrier through which neither calcium nor buffer could pass. In $C$ and $D$, both calcium and buffer could diffuse into the body, but calcium was captured instantly by an unsaturable buffer within. Shown are "time-averaged" simulations using standard parameter values (Table 1).

the body was a diffusion barrier for both calcium and buffer. For Figure $10, C$ and $D$, I assumed that the body was an unsaturable sink for calcium, and transparent to the buffer. Such a sink could arise if the body contained such a large number of calcium-binding sites that equilibrium never occurred within the time scale of these simulations, or if it contained a calcium buffer that became mobile only after binding calcium. As expected, placing a sink or a barrier so close to the cluster had major effects on the calcium concentration, although it was surprising to find that the calcium concentration within $5 \mathrm{~nm}$ of the membrane reached $100 \mu \mathrm{M}$ with an unsaturable sink only $40 \mathrm{~nm}$ away. The instantaneous calcium concentrations at the $40 \mathrm{~K}_{\mathrm{Ca}}$ channel sites were (mean $\pm \mathrm{SD}$ ) $420 \pm 80 \mu \mathrm{M}$ if the body formed a barrier, and $105 \pm 21 \mu \mathrm{M}$ if it was a sink. In either case, $C_{\mathrm{ss}}$ fell steeply beyond the edge of the cluster.

\section{A higher buffer concentration reduces depletion}

One additional simulation was carried out to show the effect of a very high buffer concentration (Fig. 11). In this case, $B_{0}$ was raised to $10 \mathrm{mM}$, and $k_{\mathrm{on}}$ lowered to $3 \times 10^{7} \mathrm{M}^{-1} \mathrm{sec}^{-1}$, to maintain the same $\tau_{c}$ as for the standard buffer. This higher concentration of buffer thus had the same effect as the standard buffer during small calcium currents that did not cause depletion (Neher, 1986; Roberts, 1993), but was much more resistant to depletion during large calcium currents. The average calcium concentration at the $\mathrm{K}_{\mathrm{Ca}}$ channel sites was $90 \pm 18 \mu \mathrm{M}\left(I_{\mathrm{Ca}}=8\right.$ $\mathrm{pA})$, and the slope of the relationship between $I_{\mathrm{Ca}}$ and $\left[\mathrm{Ca}^{2+}\right]_{i}$ was $13 \mu \mathrm{M} / \mathrm{pA}$. Comparing this value to the slope without buffer reported above $(47 \mu \mathrm{M} / \mathrm{pA})$ shows that the mobile buffer was still quite effective at $I_{\mathrm{Ca}}=8 \mathrm{pA}$ (i.e., the buffer reduced the slope by $72 \%$ ).

\section{Discussion}

\section{Comparing theory to experiments}

The simulations of buffered calcium diffusion presented in this article show that a calcium-binding protein, such as the $28 \mathrm{kDa}$ calbindin or related protein that is abundant in many types of hair cells, can have a major impact on the local calcium concentration near a cluster of channels if it is present in sufficient concentration to provide millimolar concentrations of mobile calcium-binding sites. These findings demonstrate the feasibility of the mechanism that I proposed to explain experimental find- 
ings obtained from frog saccular hair cells (Roberts, 1993). This model was based upon comparisons between the effects exogenous calcium buffers introduced through whole-cell recording pipettes, and the cell's endogenous calcium buffer capacity measured using the perforated-patch technique (Korn et al., 1991). The simulations reproduced the two main experimental findings: (1) the buffer reduced the calcium concentration reported by $\mathrm{K}_{\mathrm{Ca}}$ channels, and (2) the buffer was significantly depleted by a calcium current of $8 \mathrm{pA}(=24$ ions $/ \mu \mathrm{sec}=12 \%$ of calcium channels open). The standard buffer appeared to suffer somewhat greater depletion than the hair cell's native buffer, as judged by the slope of the relationship between $I_{\mathrm{Ca}}$ and $C_{\mathrm{ss}}$ at $I_{\mathrm{Ca}}=8$ pA (compare the calculated 13\% reduction in this slope to the $\sim 40 \%$ reduction shown in Fig. $3 A$ of Roberts, 1993). This slope is an important factor in determining the frequency and damping of the hair cell's electrical resonance (Ashmore and Attwell, 1985), and presumably is equally important in setting the steepness of the relationship between presynaptic depolarization (which opens the calcium channels) and postsynaptic response. If frog saccular hair cells contained only $2 \mathrm{~mm}$ of the standard buffer, the buffer's effect would be limited to shifting the voltage dependence of calcium-mediated processes, but could have little influence on the steepness of their voltage dependence once the buffer was depleted.

Theorems 1 and 2 can be used to make quantitative estimates of $B_{0}$ and $k_{\text {on }}$ from the previous experimental data. When comparing the effects of high-affinity exogenous buffers, such as BAPTA, to the native buffer, Theorem 1 states that there are three properties that may determine $C_{\mathrm{ss}}: \tau_{c}, R$, and $K_{d}$. The $K_{d}$ for BAPTA is $\sim 100 \mathrm{~nm}$, which may be much lower than the native buffer's $K_{d}$ (Feher et al., 1989, 1992). However, for a given value of $B_{0}, K_{d}$ makes little difference unless it is near or above $100 \mu \mathrm{M}$ (Fig. 4). $K_{d}$ does influence the total amount of buffer $\left(B_{\text {tot }}\right)$ that must be present to yield a given initial concentration of calcium-free buffer $\left(B_{0}\right)$, particularly if $K_{d}<C_{0}$. However, in the case of an exogenous buffer introduced through a whole-cell pipette, both $B_{\text {tot }}$ and $C_{0}$ are determined by the composition of the intracellular saline in the pipette, which can be adjusted to yield the desired value of $B_{0}$ (Eq. 1). The value of $B_{10 t}$ for the native buffer cannot be determined by this method, but as long as one is interested in $B_{0}$ rather than $B_{\text {tot }}$, it is reasonable to ignore possible differences in $K_{d}$. This leaves only $\tau_{c}$ and $R$ to consider.

The value of $\tau_{c}$ can be determined during very small calcium currents, in which case $R$ is not important (i.e., the buffer is not depleted; Neher, 1986; Roberts, 1993). During the smallest calcium currents that could be measured, the hair cell's endogenous buffer had the same effect on steady-state $\mathrm{K}_{\mathrm{Ca}}$ channel activation as $\sim 500 \mu \mathrm{M}$ BAPTA (Roberts, 1993). The BAPTA was introduced through large whole-cell pipettes $(2-4 \mu \mathrm{m}$ diameter) in a saline that contained $\sim 10 \mathrm{~nm}$ free calcium, which implies that nearly all of the BAPTA was initially calcium free. Therefore, the $\tau_{c}$ for the native buffer must have been similar to that of $500 \mu \mathrm{M}$ BAPTA $(3.3 \mu \mathrm{sec})$, which was the standard value used in Figures 7-11.

To separate the two factors that contribute to $\tau_{c}\left(k_{\mathrm{on}}\right.$ and $\left.B_{0}\right)$, one needs to observe the buffer's effect on $C_{\mathrm{ss}}$ during large currents that cause nearly complete local depletion (Theorem 2). During large calcium currents, the reduction in $C_{\mathrm{ss}}$ caused by the hair cell's native buffer was intermediate between the reduction caused by $800 \mu \mathrm{M}$ BAPTA and $1.6 \mathrm{~mm}$ BAPTA (Roberts, 1993). From Theorem 2, one can conclude that $800 \mu \mathrm{M} \times$
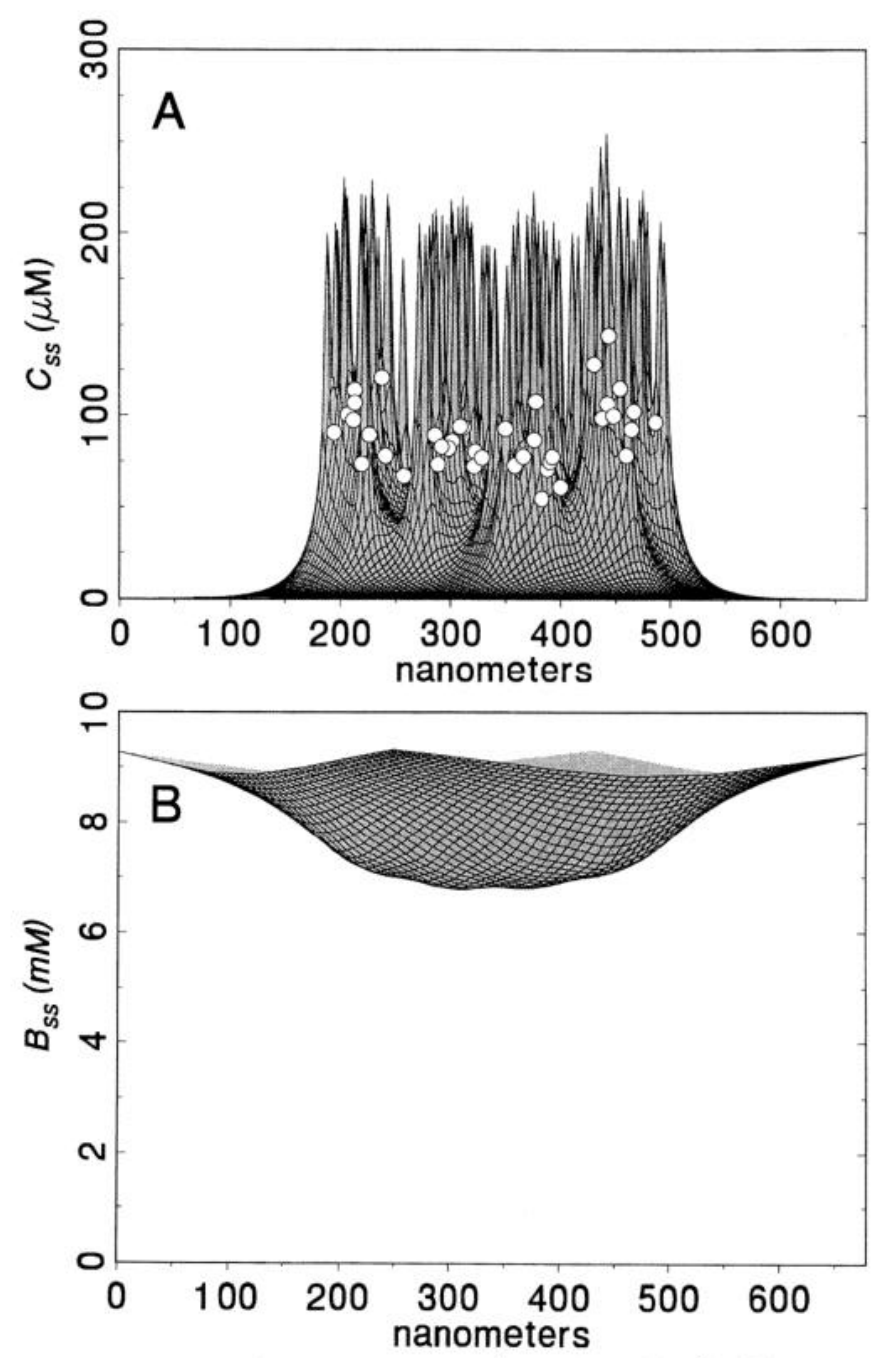

Figure 11. The "time-averaged" calcium $(A)$ and buffer $(B)$ concentrations at the membrane with a high concentration of mobile buffer $\left(B_{0}=10 \mathrm{mM}\right) . k_{\text {on }}$ was lowered to give the same value of $\tau_{c}$ as for the standard buffer. Other parameter values were the standard (Table 1).

$D_{\mathrm{BAPTA}} / D_{\mathrm{Ca}}<B_{0} D_{\mathrm{Bu}} / D_{\mathrm{Ca}}<1.6 \mathrm{~mm} \times D_{\mathrm{BAPTA}} / D_{\mathrm{Ca}}$. Several measurements of $D_{\text {BAPTA }}$ in cytoplasm (see Nowycky and Pinter, 1993 ) indicate that it is about the same as $D_{\mathrm{Ca}}$, which is 10 times the value used for $D_{\mathrm{Bu}}$ in these computations. Therefore, the data indicate that $8 \mathrm{~mm}<B_{0}<16 \mathrm{~mm}$. To test whether such high buffer concentrations would lead to less depletion than was seen with $B_{0}=2 \mathrm{mM}$, a simulation was performed using $B_{0}=$ $10 \mathrm{~mm}$ and $\tau_{c}=3.3 \mu \mathrm{sec}$ (Fig. 11). This amount of buffer appeared to suffer somewhat less depletion than the native buffer (the calculated slope of the relationship between $I_{\mathrm{Ca}}$ and $C_{\mathrm{ss}}$ was reduced by $72 \%$, compared to the slope without buffer). The data and simulations therefore suggest a native buffer concentration at the low end of the estimated range: $B_{0} \approx 8 \mathrm{~mm}$.

Since each molecule of calbindin-D28k binds four to six calcium ions (Leathers et al., 1990), the estimated value of $B_{0}$ corresponds to a calbindin concentration of $\sim 1.5 \mathrm{~mm}$. This estimate should be interpreted cautiously, since errors in the estimates of $D_{\mathrm{Bu}}$ and $D_{\text {BAPTA }}$ could give a two- to threefold error in $B_{0}$. Nevertheless, calbindin is one of the most abundant proteins in the cytoplasm of these hair cells (Shepherd et al., 1989; Gillespie and Hudspeth, 1991); calbindin or calretinin (a 29 
$\mathrm{kDa}$ protein with $58 \%$ amino acid sequence identity to calbindin-D28k; Rogers, 1987) immunoreactivity is found in hair cells from many species (Dechesne and Thomasset, 1988; Dechesne et al., 1988a,b, 1991; Rogers, 1989), and has been reportedly found in excess of $1 \mathrm{~mm}$ in some hair cells (Oberholtzer et al., 1988). If $B_{0}-8 \mathrm{mM}$, then $k_{\text {on }} \approx 4 \times 10^{7} \mathrm{M}^{-1} \mathrm{sec}^{-1}$, similar to values reported for related calcium-binding proteins (Feher et al., 1989, 1992).

Other quantitative comparisons between the experimental data and the model reveal some differences. During an $8 \mathrm{pA}$ calcium current, the mean calcium concentration reported by $\mathrm{K}_{\mathrm{Ca}}$ channels was $520 \mu \mathrm{M}$ (Roberts, 1993), which is larger that the simulations predict even without a buffer (374 $\mu \mathrm{M}$; Fig. $8 D$ ). One is tempted to attribute such a difference to the presynaptic body and densely packed synaptic vesicles slowing diffusion away from the membrane (Fig. 10A). However, given the range of possible explanations, including having assumed too large a diffusion coefficient for calcium or too great an average separation between calcium channels and $\mathrm{K}_{\mathrm{Ca}}$ channels, or a systematic error in the procedure used to estimate calcium concentrations from the activation of the $\mathrm{K}_{\mathrm{Ca}}$ current, it seems premature to try to draw any firm conclusion. In any case, the important qualitative conclusions described below, and the quantitative estimate of $B_{0}$ given above, are not significantly affected by uncertainty in the exact value of $\left[\mathrm{Ca}^{2+}\right]_{i}$. The estimate of $B_{0}$ relied upon comparisons between different buffers, and required knowing the ratio of $D_{\mathrm{BAPTA}}$ to $D_{\mathrm{Bu}}$, but not $\left[\mathrm{Ca}^{2+}\right]_{i}$.

\section{The buffer speeds the fall in $\left[\mathrm{Ca}^{2+}\right]_{\mathrm{i}}$ after channels close}

In many types of hair cells, the membrane potential undergoes a damped oscillation following any disturbance. This electrical resonance, which is part of the filter that tunes cells to particular frequencies, is produced by the calcium-mediated interaction between the calcium channels and $\mathrm{K}_{\mathrm{Ca}}$ channels that are the subject of this report. It requires that $\left[\mathrm{Ca}^{2+}\right]_{i}$ rise and fall with each cycle of the oscillation, and can occur at several hundred hertz (Crawford and Fettiplace, 1981; Ashmore, 1983; Lewis and Hudspeth, 1983; Ashmore and Attwell, 1985; Art and Fettiplace, 1987; Hudspeth and Lewis, 1988a,b; Roberts et al., 1988). A similar requirement probably exists for phase-locked synaptic transmission to occur, and is the basis of the speculation that the high concentrations of calcium-binding proteins are involved in preserving high-frequency phase information in auditory pathways (Carr, 1986; Dechesne et al., 1988; Rogers, 1989; Zettel et al., 1991). Figures 2 and 3 show that calciumbinding proteins indeed can greatly speed the falling phase of $\left[\mathrm{Ca}^{2+}\right]_{i}$ near a cluster of channels, but only if the buffer is mobile. This effect can occur despite the buffer's local depletion. A cell might thus gain an advantage by using a mobile buffer at a low enough concentration for it to be depleted locally at the site of calcium entry, thereby allowing large increases in $\left[\mathrm{Ca}^{2+}\right]_{i}$ when the channels open, while still causing a rapid fall in $\left[\mathrm{Ca}^{2+}\right]_{i}$ when the channels close. The ability of the buffer to sharpen calcium transients may be a critical part of its function.

\section{The mobile calcium buffer confines high $\left[\mathrm{Ca}^{2+}\right]_{\mathrm{i}}$ to synaptic sites}

A second potentially important function of the buffer is to keep micromolar calcium concentrations from spreading. While some neurons have evolved ways to physically isolate regions of high $\left[\mathrm{Ca}^{2+}\right]_{i}$ (e.g., dendritic spines), hair cells are compact and do not tolerate high calcium throughout the cytoplasm; when perfused internally with $>100 \mu \mathrm{M}$ calcium through a whole-cell pipette, hair cells lose their rigid cylindrical shape and become "hairballs" (spheres with protruding tufts of stereocilia; W. M. Roberts, unpublished observations). Under normal physiological conditions, the mobile buffer may defend against the spread of such high calcium levels away from the presynaptic sites by causing $\left[\mathrm{Ca}^{2+}\right]_{i}$ to decline approximately exponentially with distance from the channel cluster, with a space constant of $<50$ nm (Figs. 7-11). Similar local effects of mobile calcium-binding proteins might also be important in their apparent ability to protect cells from calcium toxicity (Baimbridge et al., 1981; Mattson et al., 1991).

The difference between a calcium concentration that falls inversely with distance (without a mobile buffer) and exponentially with distance (with a mobile buffer; Neher, 1986) may seem subtle, but is in fact quite important. A good example to consider is the case of calcium channels spread uniformly over a large, flat area of membrane. Without a mobile buffer, the contribution of an individual channel to the $\left[\mathrm{Ca}^{2+}\right]_{i}$ at a distance $r$ declines in proportion to $1 / r$ (Crank, 1975; see Roberts et al., 1990). However, this decline is offset by the larger number of channels at greater distances, which increases in proportion to $r$. Therefore, the net contribution of all channels at distance $r$ from any point near the membrane does not decline as $r$ increases. In other words, if the decline in $\left[\mathrm{Ca}^{2+}\right]_{i}$ is no steeper than $1 / r$, the effect of the large number of distant calcium sources is as great as the smaller number of nearby sources. By increasing the steepness of this decline, the mobile buffer effectively silences these distant sources, creating highly localized concentration changes. Similarly, the mobile buffer can isolate each presynaptic active zone from the effects of neighboring active zones that are more than a few hundred nanometers distant.

\section{The difference between instantaneous and time-averaged calcium concentrations}

The likely possibility that individual calcium receptors experience widely varying calcium concentrations that depend upon the random opening of nearby channels (Fig. $8 A, B$ ) has important consequences for the interpretation of the average behavior of receptors that have a nonlinear dependence on $\left[\mathrm{Ca}^{2+}\right]_{i}$. This difficulty has previously been investigated with respect to calcium-mediated exocytosis, where the apparent cooperativity of calcium action in triggering transmitter release was found to vary between 1 and $>4$ (e.g., Katz and Miledi, 1970; Llinás et al., 1982). One interpretation is that these differences depended upon whether the change in calcium influx was due to a change in the current through each open channel or to a change in the number of open channels, and if the number of open channels did change, whether a calcium receptor was likely to be close to more than one open channel (Fogelson and Zucker, 1985; Zucker and Fogelson 1986; reviewed by Augustine et al., 1991; but see Simon and Llinás, 1985; Llinás, 1991). A similar difficulty arises in using whole-cell $\mathrm{K}_{\mathrm{Ca}}$ currents to deduce kinetic schemes for the binding of calcium to individual $\mathrm{K}_{\mathrm{Ca}}$ channels (Hudspeth and Lewis, 1988b) or to infer $\left[\mathrm{Ca}^{2+}\right]_{i}$ (Roberts, 1993). Such an error may explain why the relationship between $I_{\mathrm{Ca}}$ and $\left[\mathrm{Ca}^{2+}\right]_{i}$ inferred from whole-cell $\mathrm{K}_{\mathrm{Ca}}$ currents was not a straight line through the origin when no calcium buffer was present (Roberts, 1993). Given the expected complexity of the spatial and temporal changes in $\left[\mathrm{Ca}^{2+}\right]_{i}$, it is impressive that these cells can so accurately regulate the kinetic properties of their $\mathrm{K}_{\mathrm{Ca}}$ channels, as is required to produce a particular frequency of 
electrical resonance (Ashmore and Attwell, 1985). The possible role of the mobile buffer in regulating the resonant frequency has yet to be determined.

\section{The sites of vesicle fusion}

One of the most striking features of the calcium profile predicted by these simulations is its steep falloff at the edge of the channel array, compared to a more gradual decline without a mobile buffer. Therefore, it would seem reasonable to expect that the calcium-binding sites that trigger synaptic exocytosis in these hair cells would be as close to the calcium channels as they are at other synapses, where the concentration of mobile calcium buffer is probably much lower. In freeze-fracture preparations, sites of vesicle fusion with the presynaptic membrane may sometimes be visible as shallow depressions located immediately adjacent to the active zone particle arrays (Heuser et al., 1974; Walrond and Reese, 1985), within $50 \mathrm{~nm}$ of the putative calcium channels. In hair cells, similar depressions are common, but are usually located 100-200 nm from the edge of the particle array (Fig. 6; Hama, 1980; Jacobs and Hudspeth, 1990), where $\left[\mathrm{Ca}^{2+}\right]_{i}$ is predicted to be much lower than within the array. The buffered diffusion model thcreforc supports the interpretation of Hama (1980) that these depressions at hair cell active zones are not fusion sites, but instead are the openings of coated pits and/or anastomosing tubules that may be involved in membrane recycling. Based upon transmission electron micrographs showing rows of synaptic vesicles (Hama and Saito, 1977) and occasional $\Omega$-figures (Jacobs and Hudspeth, 1990) in the narrow space between the synaptic body and the presynaptic membrane, freeze-fracture preparations showing possible vesicle attachment sites in the furrows between rows of intramembrane particles (Hama, 1980), and the steep decline in $\left[\mathrm{Ca}^{2+}\right]_{i}$ with distance from the channel array, it is most likely that the exocytotic sites at hair cell synapses are located alongside the calcium channels (Hama, 1970), as they are at other synapses, and that the more distant depressions in the membrane are associated with rapid membrane recycling needed to balance the high resting rate of transmitter release in these nonspiking cells.

Our understanding of synaptic transmission in hair cells is clearly still rudimentary. In particular, direct measurements of how transmitter release depends on calcium and calcium buffers would be very useful. The theoretical results presented in this study, in conjunction with previous experimental findings, indicate that a mobile cytoplasmic calcium buffer, possibly calbindin-D28k, is an important part of the short-range calcium signaling involved in synaptic transmission and electrical resonance in these cells.

\section{References}

Adler EM, Augustine GJ, Duffy SN, Charlton MP (1991) Alien intracellular chelators attenuate neurotransmitter release at the squid giant synapse. J Neurosci 11:1496-1507.

Art JJ, Fettiplace R (1987) Variation of membrane properties in hair cells isolated from the turtle cochlea. J Physiol (I ond) 385:207-242.

Ashmore JF (1983) Frequency tuning in a frog vestibular organ. Nature 304:536-538.

Ashmore JF, Attwell D (1985) Models for electrical tuning in hair cells. Proc R Soc Lond [Biol] 226:325-344.

Augustine GJ, Charlton MP, Smith SJ (1985) Calcium entry into voltage-clamped presynaptic terminals of squid. J Physiol (Lond) 367: 143-162.

Augustine GJ, Adler EM, Charlton MP (1991) The calcium signal for transmitter secretion from presynaptic nerve terminals. Ann NY Acad Sci 635:365-381.
Baimbridge KG, Miller JJ, Parkes CO (1981) Calcium-binding protein distribution in the rat brain. Brain Res 239:519-525.

Balkema GW (1991) A synaptic antigen (B16) is localized in synaptic ribbons. J Comp Neurol 315:573-583.

Bronner F (1989) Renal calcium transport: mechanisms and regulation - an overview. Am J Physiol 257:F707-F711.

Callaway JC, Lasser-Ross N, Stuart AE, Ross WN (1993) Dynamics of intracellular free calcium concentration in the presynaptic arbors of individual barnacle photoreceptors. J Neurosci 13:1157-1166.

Carr CE (1986) Time coding in electric fish and barn owls. Brain Behav Evol 28:122-133.

Chad JE, Eckert R (1984) Calcium domains associated with individual channels can account for anomalous voltage relations of $\mathrm{Ca}$-dependent responses. Biophys J 45:993-999.

Cohen MW, Jones OT, Angelides KJ (1991) Distribution of $\mathrm{Ca}^{2+}$ channels on frog motor nerve terminals revealed by fluorescent $\omega$-conotoxin. J Neurosci 11:1032-1039.

Connor JA, Nikolakopoulou G (1982) Calcium diffusion and buffering in nerve cytoplasm. Lect Math Life Sci 15:79-101.

Crank J (1975) The mathematics of diffusion. Sunderland, MA: Sinauer.

Crawford AC, Fettiplace R (1981) An electrical tuning mechanism in turtle cochlear hair cells. J Physiol (Lond) 312:377-412.

Dechesne CJ, Thomasset M (1988) Calbindin (CaBP $28 \mathrm{kDa}$ ) appearance and distribution during development of the mouse inner ear. Dev Brain Res 40:233-242.

Dechesne CJ, Thomasset M, Brehier A, Sans A (1988a) Calbindin (CaBP 28kDa) localisation in the peripheral vestibular system of various vertebrates. Hearing Res 33:273-278.

Dechesne CJ, Lavigne-Rebillard M, Brehier A, Thomasset M, Sans A (1988b) Appearance and distribution of neuron-specific enolase and calbindin (CaBP 28kDa) in the developing human inner ear. Dev Brain Res 41:221-230.

Dechesne CJ, Winsky L, Kim HN, Goping G, Vu TD, Wenthold RJ, Jacobowitz DM (1991) Identification and ultrastructural localization of a calretinin-like calcium-binding protein (protein 10) in the guinea pig and rat inner ear. Brain Res 560:139-148.

Delaney K, Zucker RS, Tank DW (1989) Calcium in motor nerve terminals associated with posttetanic potentiation. J Neurosci 9:3558 3567.

Delaney K, Tank DW, Zucker RS (1991) Presynaptic calcium and serotonin-mediated enhancement of transmitter release at crayfish neuromuscular junction. J Neurosci 11:2631-2643.

Engel AG (1991) Review of evidence for loss of motor nerve terminal calcium channels in Lambert-Eaton myasthenic syndrome. Ann NY Acad Sci 635:246-258.

Feher JJ, Fullmer CS, Fritzsch GK (1989) Comparison of the enhanced steady-state diffusion of calcium by calbindin-D9K and calmodulin: possible importance in intestinal calcium absorption. Cell Calcium 10:189-203.

Feher JJ, Fullmer CS, Wasserman RH (1992) Role of facilitated diffusion of calcium by calbindin in intestinal calcium absorption. Am J Physiol 262:C517-C526.

Fogelson AL, Zucker RS (1985) Presynaptic calcium diffusion from various arrays of single channels. Implications for transmitter release and synaptic facilitation. Biophys J 48:1003-1017.

Gillespie PG, Hudspeth AJ (1991) High-purity isolation of bullfrog hair bundles and subcellular and topological localization of constituent proteins. J Cell Biol 112:625-640.

Gleisner L, Flock A, Wersäll J (1973) The ultrastructure of the afferent synapse on hair cells in the frog labyrinth. Acta Otolaryngol (Stockh) 76:199-207

Hama K (1980) Fine structure of the afferent synapse and gap junctions on the sensory hair cell in the saccular macula of goldfish: a freezefracture study. J Neurocytol 9:845-860.

Hama K, Saito K (1977) Fine structure of the afferent synapse of the hair cells in the saccular macula of goldfish, with special reference to the anastomosing tubules. J Neurocytol 6:361-373.

Heuser JE, Reese TS, Landis DMD (1974) Functional changes in frog neuromuscular junctions studied with freeze-fracture. J Neurocytol 3:109-131.

Hudspeth AJ, Lewis RS (1988a) Kinetic analysis of voltage- and iondependent conductances in saccular hair cells of the bull-frog Rana catesbeiana. J Physiol (Lond) 400:237-274.

Hudspeth AJ, Lewis RS (1988b) A model for electrical resonance and 
frequency tuning in saccular hair cells of the bull-frog Rana catesbeiana. J Physiol (Lond) 400:275-297.

Jacobs RA, Hudspeth AJ (1990) Ultrastructural correlates of mechanotransduction in hair cells of the bullfrog's sacculus. Cold Spring Harbor Symp Quant Biol 55:547-561.

Katz B, Miledi R (1970) Further study of the role of calcium in synaptic transmission. J Physiol (Lond) 207:789-801.

Korn SJ, Marty A, Connor JA, Horn R (1991) Perforated patch recording. Methods Neurosci 4:364-373.

Kutchai H, Jacquez JA, Mather FJ (1970) Nonequilibrium facilitated oxygen transport in hemoglobin solution. Biophys $\mathbf{J}$ 10:38-54.

Lancaster B, Nicoll RA (1987) Propertics of two calcium-activated hyperpolarizations in rat hippocampal neurones. $J$ Physiol (Lond) 389:187-203.

Leathers VL, Linse S, Forsén S, Norman AW (1990) Calbindin-D28K a la25-dihydroxyvitamin $\mathrm{D} 3$-induced calcium-binding protein binds five or six $\mathrm{Ca}^{2+}$ ions with high affinity. J Biol Chem 265:9838-9841.

Lewis RS, Hudspeth AJ (1983) Voltage- and ion-dependent conductances in solitary vertebrate hair cells. Nature 304:538-541.

Llinás R (1991) Depolarization release coupling: an overview. Ann NY Acad Sci 635:3-17.

Llinás R, Steinberg IZ, Walton K (1981) Relationship between presynaptic calcium current and postsynaptic potential in squid giant synapse. Biophys J 33:323-352.

Llinás R, Sugimori M, Simon SM (1982) Transmission by spike-like depolarizations in the squid synapsc. Proc Natl Acad Sci USA 79: 2415-2419.

Llinás R, Sugimori M, Silver RB (1992) Microdomains of high calcium concentration in a presynaptic terminal. Science 256:677-679.

Mattson MP,'Rychlik B, Chu C, Christakos S (1991) Evidence for calcium-reducing and excito-protective roles for the calcium-binding protein calbindin-D28k in cultured hippocampal neurons. Neuron 6:41-51.

Neher E (1986) Concentration profiles of intracellular calcium in the presence of a diffusible chelator. In: Calcium electrogenesis and neuronal functioning (Heinemann U, Klee M, Neher E, Singer W, eds), pp 80-96. Berlin: Springer.

Nowycky MC, Pinter MJ (1993) Time courses of calcium and calciumbound buffers following calcium influx in a model cell. Biophys $\mathrm{J} 64$ : 77-91.

Oberholtzer JC, Buettger C, Summers MC, Matschinsky FM (1988) The $28-\mathrm{kDa}$ calbindin-D is a major calcium-binding protein in the basilar papilla of the chick. Proc Natl Acad Sci USA 85:3387-3390.

Parnas H, Hovav G, Parnas I (1989) Effect of $\mathrm{Ca}^{2+}$ diffusion on the time course of neurotransmitter release. Biophys J 55:859-874.

Popov S, Poo MM (1992) Diffusional transport of macromolecules in developing nerve processes. J Neurosci 12:77-85.

Pumplin DW, Reese TS, Llinás R (1981) Are the presynaptic membrane particles the calcium channels? Proc Natl Acad Sci USA 78: 7210-7213.

Roberts WM (1993) Spatial calcium buffering in saccular hair cells. Nature 363:74-76.

Roberts WM, Hagedorn M (1992) Cytoplasm of frog saccular hair cells has a calcium buffer more effective than $0.5 \mathrm{~mm}$ BAPTA. Biophys J 61:A142.
Roberts WM, Howard J, Hudspeth AJ (1988) Hair cells: transduction tuning and transmission in the inner ear. Annu Rev Cell Biol 4:6392.

Roberts WM, Jacobs RA, Hudspeth AJ (1990) Colocalization of ion channels involved in frequency selectivity and synaptic transmission at presynaptic active zones of hair cells. J Neurosci 10:3664-3684.

Roberts WM, Jacobs RA, Hudspeth AJ (1991) The hair cell as a presynaptic terminal. Ann NY Acad Sci 635:221-233.

Robitaille R, Charlton MP (1992) Presynaptic calcium signals and transmitter release are modulated by calcium-activated potassium channels. J Neurosci 12:297-305.

Rogers JH (1987) Calretinin: a gene for a novel calcium-binding protein expressed principally in neurons. J Cell Biol 105:1343-1353.

Rogers JH (1989) Two calcium-binding proteins mark many chick sensory neurons. Neuroscience 31:697-709.

Sala F, Hernández-Cruz A (1990) Calcium diffusion modeling in a spherical neuron. Relevance of buffering properties. Biophys $J 57$ : 313-324.

Shepherd GMG, Barres BA, Corey DP (1989) "Bundle blot" purification and initial protein characterization of hair cell stereocilia. Proc Natl Acad Sci USA 86:4973-4977.

Simon SM, Llinás RR (1985) Compartmentalization of the submembrane calcium activity during calcium influx and its significance in transmitter release. Biophys J 48:485-498.

Smith SJ, Augustine GJ (1988) Calcium ions active zones and synaptic transmitter release. Trends Neurosci 11:458-464.

Speksnijder JE, Miller AL, Weisenseel MH, Chen T-H, Jaffe LF (1989) Calcium buffer injections block fucoid egg development by facilitating calcium diffusion. Proc Natl Acad Sci USA 86:6607-6611.

Stockbridge N, Moore JW (1984) Dynamics of intracellular calcium and its possible relationship to phasic transmitter release and facilitation at the frog neuromuscular junction. J Neurosci 4:803-811.

Stockbridge N, Ross WN (1984) Localized $\mathrm{Ca}^{2+}$ and calcium activated potassium conductances in terminals of a barnacle photoreceptor. Nature 309:266-268.

Swandulla D, Hans M, Zipser K, Augustine GJ (1991) Role of residual calcium in synaptic depression and posttetanic potentiation: fast and slow calcium signalling in nerve terminals. Neuron 7:915-926.

Walrond JP, Reese TS (1985) Structure of axon terminals and active zones at synapses on lizard twitch and tonic muscle fibers. J Neurosci $5: 1118-1131$.

Yamada WM, Zucker RS (1992) Time course of transmitter release calculated from simulations of a calcium diffusion model. Biophys J 61:671-782.

Zettel ML, Carr CE, O’Neill WE (1991) Calbindin-like immunoreactivity in the central auditory system of the mustached bat, Pteronotus parnelli. J Comp Neurol 313:1-16.

Zucker RS, Fogelson AL (1986) Relationship between transmitter release and presynaptic calcium influx when calcium enters through discrete channels. Proc Natl Acad Sci USA 83:3032-3036.

Zucker RS, Stockbridge N (1983) Presynaptic calcium diffusion and the time courses of transmitter release and synaptic facilitation at the squid giant synapse. J Neurosci 3:1263-1269. 